\title{
Shareholder Dividend Options
}

\author{
Zohar Goshen ${ }^{\dagger}$
}

\section{CONTENTS}

I. THE USE OF Dividend POlicy To Reduce Agency Costs . . . . . 885

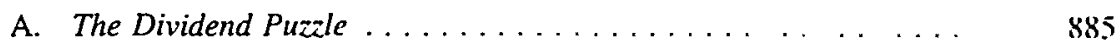

B. Agency-Cost Theory and Stable Dividends ........ . . . . 887

C. Alternatives to Stable Dividends for Reducing Agency Costs . . . . 893

1. The Takeover Mechanism .................. . 893

2. Debt Financing ..................... . 896

3. Shareholder Dividend Voting ............... 899

4. Shareholder Dividend Options . . . . . . . . . . . . 903

II. IMPEDIMENTS to the Adoption of AN OPTION MeChaNisM $\ldots \ldots \ldots . .906$

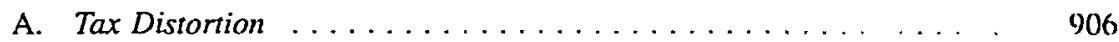

1. The Problem ..................... .906

2. Dividend Reinvestmem Plans .............. . 908

B. Removing the Tax Distortion ............. . . .910

1. Taxing an Option Based on lts Acrual Exercise ... . . . . 910

2. Total Integration of Corporate Tax . . . . . . . . . . . 915

3. Taxation Without Realization ................ 916

III. Direct Regulation of Dividend Policy $\ldots \ldots \ldots \ldots \ldots \ldots \ldots . .917$

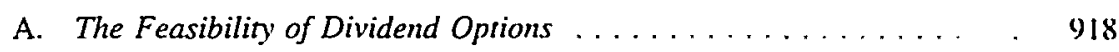

1. Defining Earnings and Working Capiral ............ 918

2. Creditors' Constraints on Dividends . . . . . . . . . . 926

B. The Role of the Courts ................... . 928

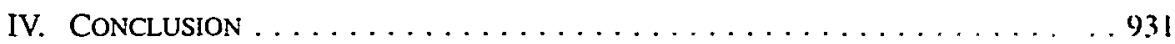

$\dagger$ Lecturer, Hebrew University. Jerusalem; LLM. J SD. Yale Law Sihool. LL B. Hebrew University, Jerusalem. This Article is based on part of my J S.D disseration at the Yale Lau School $1 \mathrm{am}$ extremely grateful to Professors Roberta Romano and Alan Schwartz for therr comments and suggestions I also acknowledge, with thanks, the comments of Eyal Benvenisu, Hanoch Dagan. Tala Dagan. Alon Harel, Irit Haviv-Segal, Ariel Porat, Edward B. Rock. Kim Treiger, and espectally Mattheu Palmer Above all, I wish to express my deepest thanks to my supervisor Professor Henry Hansmann, who has offered me not only his invaluable intellectual expertise. but also his constant suppon. guidance, and fnendshup 
A firm's dividend policy reflects management's decision as to what portion of accumulated earnings will be distributed to shareholders and what portion will be retained for reinvestment. ${ }^{\prime}$ A firm's retained earnings represent the amount of financing that the firm can utilize without having to compete against other firms in the capital markets. Because dividend policy wholly determines the amount of earnings that a firm retains, dividend policy also determines the extent to which a firm can escape the scrutiny of participants in the capital markets.

Retained earnings are the greatest source of capital for firms. The typical U.S. industrial corporation finances almost seventy-five percent of its capital expenditures from retained earnings, whereas new equity issues provide a negligible fraction of corporate funding. ${ }^{2}$ Scholars have long recognized firms' significant dependence on retained earnings and negligible dependence on equity financing. ${ }^{3}$ This phenomenon led Professor Baumol to the inescapable conclusion that a substantial proportion of firms "manage to avoid the direct disciplining influences of the securities market, or at least to evade the type of discipline which can be imposed by the provision of funds to inefficient firms only on extremely unfavorable terms." Unfortunately for the sake of allocative efficiency, in recent years, most firms have also managed to avoid even the indirect disciplining influences of the market for corporate control. ${ }^{5}$

Inefficient managers might try to escape a market inspection of their performance by adopting a low-payout dividend policy and avoiding the

1. The result of this decision is referred to as the firm's dividend payout ratio: the ratio between earnings distributed as dividends and total earnings (dividends / total earnings = payout ratio).

2. From 1981 to 1991 , U.S. corporations financed $74.7 \%$ of their new investments from internally generated cash flow. The figure of $74.7 \%$ represents net income plus depreciation minus dividends. Between 1981 and 1991, average new equity financing was about $-11 \%$, as firms repurchased more shares than they issued. See Stephen A. Ross et AL., Corporate Finance 406 tbl. 14.1 (3d cd. 1993). Moreover, on average, publicly traded firms issue "seasoned" equity-additional equity issued by a firm whose shares are already traded in public markets-only once every 18.5 years. See Lynn A. Stout. The Unimportance of Being Efficient: An Economic Analysis of Stock Market Pricing and Securities Regulation. $87 \mathrm{MICH}$. L. REV. 613, $647 \mathrm{n} .186$ (1988). The portion of corporate funding that does not come from either retained earnings or equity is raised through debt financing. See id. at 648 .

3. See, e.g., WILliam J. BAUMOL, THE STOCK MARKET AND ECONOMIC EFFICIENCY 69 (1965); Gordon Donaloson, Corporate DebT Capacity 56 (1961).

The proclivity of U.S. firms to finance their capital expenditures from internally generated cash flows is almost without parallel in the world of international corporate finance. Compared to U.S. corporations, firms in other countries finance much less of their capital expenditures from internal cash flow and much more of their capital expenditures from new equity issues. Germany is the only major industrial country whose firms generate as much financing internally as do U.S. firms. See ROSS ET AL., supra note 2, at $408-09$.

4. BAUMOL, supra note 3, at 70 . For this reason, Baumol noted that "[o]ne might almost venture to conclude ... that the market in fact does not allocate much of the economy's capital." Id. at 79. Market pricing of new stock issues directly influences the allocative efficiency of the economy by determining firms' cost of capital. The fact that the market allocates so little capital, however, has provided grounds for doubting the importance of capital markets efficiency. See Stout, supra note 2, at 617-18.

5. See Stout, supra note 2, at 691 (contending that managerial defensive tactics and state antitakeover legislation have raised costs of hostile takeover significantly above that which would be incurred in frec market for corporate control). 
competitive external market for financing. ${ }^{6}$ Seemingly oblivious to this threat of managerial opportunism, state courts have established that directors possess sole discretion over whether or not to declare dividends, and that, absent abuse of discretion, the law will not second-guess the business judgment of corporate officers. $^{7}$ The general rule is that only fraud, bad faith, or gross mismanagement can justify compelling distribution. ${ }^{8}$ This rule removes any effective limit on managerial decisions concerning the timing and quantity of dividend distributions.

In granting management the protection of the business judgment rule, courts have placed a heavy burden on shareholders who wish to challenge management's dividend policy. A shareholder suit to compel dividend distribution, based on the claim that management is investing in bad (negative net present value) projects, has virtually no chance of succeeding. In fact, in the last one hundred years, there has not been a single case in which U.S. courts have ordered a management-controlled, publicly traded corporation to increase the dividend on its common stock. ${ }^{9}$

Although a few scholars have recognized the need to restrain managerial discretion over dividend policy, ${ }^{10}$ a thorough analysis of the dividend policy

6. The risk of managerial abuse of discretion is known as agency cost See Michael C Jensen \& William H. Meckling, Theory of the Firm: Managenal Behavior. Agency Costs and Uwnership Siructure. 3 J. FIN. ECON. 305, 310-11 (1976). Indeed, as some of the literature on takeovers suggests, many managers do abuse their discretion and retain excessive eamings See. e.g. Michael C Jensen. Agency Costs of Free Cash Flow, Corporate Finance, and Takeovers. 76 AM ECON REV 323 (1986) [hereinafter Jensen, Agency Costs].

7. State corporate law does preclude managers from paying excessive dividends to shareholders "Historically, the principal objective of dividend law has therefore been the preservation of a mumum of assets as a safeguard in assuring the payment of creditors" claims "D. KEIL. CORPORATE DividENOS 14-15 (1941). What has been true historically remans true today. One of the leading corporate law casebooks devotes almost $90 \%$ of its section on dividends to a discussion of the upper legal limis on management's distributions. See WILliam L. CARY \& Melvin aron EISENBerg. Corporations. Cases AND MATERIALS 1294-1375 (6th ed. 1988).

8. See, e.g. Berwald v. Mission Dev. Co., 185 A.2d 480. 482-83 (Del 1962). Kamin I Amencan Express Co., 383 N.Y.S.2d 807. $811-12$ (Sup. CL), aff'd. 387 N.Y.S.2d 993 (App Div 1976), ViCTOR BRUdNey \& Marvin A. CHIRELSTEIN, Corporate FINANCE 502 (3d ed 1987), harky G HeNA \& Join R. AlEXANDER, LAWS OF CORPORATIONS 913-14 (3d ed. 1983). David $\mathrm{M}$ istael. Note. The Business Judgment Rule and the Declaration of Corporate Dividends A Reapprausal. 4 HOFSTRA L REV 73.74 (1975).

9. See Merrit B. Fox, FINANCE ANd Industrial Performiance in A DYNasil Ecovouy 375 (1987). Courts have treated closely held corporations much like parnerships. Thus, suits for compelling dividends in closely held corporations have been more successful for a famous example. see Dodge $v$ Ford Motor Co., 170 N.W. 668 (Mich. 1919).

10. See, e.g., BRUDNEY \& CHIRELSTEIN, supra note 8. at 517 (asserting that if management systematically prefers retaining earnings to paying out dividends. then disputes with shareholders over dividend policy might reflect conflict of interest rather than differing business judgments and legal norm should involve fiduciary duty of loyalty to shareholders): Victor A Brudney. Dividends. Discreston, and Disclosure, 66 VA. L. REV. 85 (1980) ("The inability to impose feasible limis on management's discretion in making the dividend decision underscores the significance of defining the extent of management's obligation to convey the information content of the dividend decision."); Israel. supra note 8. at 98 ("A better solution to unwarranted retention would be to delimit the parameiers of the business judgment rule as it applies to the declaration of corporate dividends, thereby minimuzing management's potentual for abuse of its powers."). 
issue has not appeared in either the law review or finance literature." Moreover, to date, proposals to reform dividend law have been ineffective. ${ }^{12}$ In general, the body of legal literature on dividend policy is sparse; this Article provides a much-needed analysis of how the law ought to regulate managerial decisions regarding dividend policy.

This Article proposes a legal norm that shifts discretion over dividend policy from managers to the capital markets (i.e., shareholders). ${ }^{13}$ State corporate law could effect such a shift by adopting a rule that mandates shareholder control over the dividend decision. The rule would require every firm to adopt an option mechanism that, at predetermined dates, provided each of the firm's shareholders with the right to select either cash or stock dividends in an amount equal to the shareholder's pro rata share of the firm's earnings. For instance, the law might require that, once a year, the firm offer to each shareholder the right to decide what percentage of her share of earnings she will take out of the firm-through a cash dividend-and what percentage she will leave in the firm-through a stock dividend. The option mechanism would be a cost-effective vehicle for assigning control over a firm's accumulated earnings to the capital markets.

Theory and evidence suggest that an unfettered management retains an excessive amount of earnings. ${ }^{14}$ Entrusting the capital markets with control over the earnings reinvestment decision would facilitate optimal earnings retention by firms ${ }^{15}$ and lessen the need for the indirect and expensive discipline provided by the market for corporate control. ${ }^{16}$ Moreover, by giving

11. This dearth of analysis is mainly due to the immaturity of finance theory when scholars wrote the leading legal articles on dividend policy. See Brudney, supra note 10 (advocating mandatory disclosure of reasons underlying dividend decisions); see also Daniel R. Fischel, The Law and Economics of Dividend Policy, 67 VA. L. REv. 699 (1981) (criticizing Brudney and arguing in favor of current law). These articles show a sophisticated use of finance theory, but they appeared before the development of the compelling agency-cost explanation of dividend policy. See Frank H. Easterbrook, Two Agency-Cost Explanations of Dividends, 74 AM. ECON. REV. 650 (1984) (arguing that main function of dividends is to align managerial incentives with incentives of shareholders); Michael S. Rozeff, Growth. Beta and Agency Costs as Determinants of Dividend Payout Ratios, 5 J. FIN. RES. 249 (1982) (suggesting that high dividend payout policies raise transaction costs of external financing but lower agency costs of management). A more recent article simply neglects to analyze the agency-cost explanation. See Richard A. Booth, Junk Bonds, the Relevance of Dividends and the Limits of Managerial Discretion, 1987 CoLUM. BUS. L. REv. 553.

12. See infra part III.B.

13. In all aspects relevant to this Article, the capital markets operate through the actions of particular shareholders. The capital markets generally function through shareholders' pricing of shares (through purchase and sale of shares) and shareholders' exercise of voting rights.

14. See infra notes 29-36 and accompanying text.

15. Shifting discretion over dividend policy to shareholders would allow them to force distribution of dividends every time they believed the internal profitability of the firm to be insufficient.

16. The market for corporate control, or the takeover market, is an external mechanism for controlling agency costs in publicly held corporations. Outsiders can oust ineffective managers by making direct appeals to a firm's residual claimants:

The market for corporate control requires and presumes a high positive correlation between corporate managerial efficiency and stock price. The stock price of a poorly managed company declines relative to its industry or the market as a whole. A lower stock price facilitates takeover by giving the prospect of a large capital gain to those who believe that they can manage the company more efficiently. Thus, the takeover market provides some assurance 
the capital markets some control over the allocation of approximately seventyfive percent of corporate expenditures, shareholder dividend options would enhance the importance of capital markets in achieving allocative efficiency. ${ }^{17}$

Part I of this Article analyzes the role of dividend policy in reducing agency costs. It begins by presenting the "dividend puzzle" and questioning why distribution of dividends affects a firm's value, given the theoretical irrelevance of dividend policy. This Part then rehearses the agency-cost explanation for the existence of dividends. Next, it compares the current practice of firms-maintaining a stable dividend distribution-with alternative mechanisms for controlling agency costs. Finally, it argues for the superiority of shareholder dividend options.

Part II explores why firms do not voluntarily adopt the option mechanism in spite of its superiority to current practice. The most likely explanation is the tax distortion in the Internal Revenue Code that would require current taxation of shareholders receiving a dividend option. Indeed, to the extent that firms are willing to sustain tax costs, they do adopt an option mechanism to enhance efficiency: dividend reinvestment plans. The remainder of the Part considers means of removing the tax distortion.

Part III considers the justification for and workability of a corporate law rule mandating the option mechanism. It argues that a mandatory rule is justified by the need to improve the performance of inefficient firms by exposing them to the scrutiny of the capital markets. It also demonstrates the feasibility of mandating the option mechanism and discusses the role of the courts in implementing dividend options. Part IV summarizes the preceding arguments and concludes that shifting control over dividend policy to shareholders is desirable and should be implemented, albeit gradually.

\section{The Use of Dividend Policy To Reduce Agency Costs}

\section{A. The Dividend Puzzle}

The logical starting point for any discussion about dividends is the "Irrelevance Theorem" of Modigliani and Miller. ${ }^{18}$ According to this theorem, if a firm's investment policy is predetermined and immutable, dividend policy cannot affect the firm's value. If a firm does not distribute dividends, the price of its equity will rise proportionally with earnings, and investors can obtain a

of competitive efficiency among corporate managers ....

J. FRED Weston et AL., MERgers, RestruCturing. ANd Corporate CoNtrol 45 (1990) (hereinaftet MERGERS AND RESTRUCTURING]. For an introduction to the economics of the mariet for corporate control. authored by the "inventor" of the concept, see Henry G. Manne. Mergers and the Mlarket for Corporase Control. 73 J. POL. ECON. 110 (1965).

17. See Stout, supra note 2, at 648.

18. Merton H. Miller \& Franco Modigliani. Dividend Policy: Growth and the Valuatuon of Shares. 34 J. Bus. 411 (1961). 
"homemade dividend" by selling a fraction of their shares on the market and liquidating their capital gains. On the other hand, if a firm does distribute dividends, and hence finances new investment by raising funds in the capital markets, the price of its equity will decline in proportion to the dividend payout. The capital markets, therefore, should be indifferent as to whether or not a firm distributes dividends, because in either case the investor possesses the same amount of wealth. Nevertheless, given the high costs of raising new funds in the capital markets and the inferior tax treatment of cash dividends compared to capital gains, ${ }^{19}$ distributing dividends will generally reduce the value of the firm. Consequently, no prudent management should pay out dividends. In practice, however, managers do not behave as if they subscribe to the irrelevance theorem. Firms do distribute dividends, and management's promise to increase the dividend payout ratio usually leads to increases in the price of the firm's equity. Actual practice suggests that investors and managers do care about dividend policy. This conflict between theory and practice is known as the "dividend puzzle."

The literature on dividend policy revolves around this puzzle. Why do managers distribute dividends at all? Why do investors care about dividends? Scholars have offered various explanations. First, dividends might have information or signaling effects: Managers might change their firm's dividend payout ratio to signal their forecast of the firm's future performance. ${ }^{21}$ Second, tax rates drive investors to hold stock in firms with particular payout ratios: Other things being equal, low tax bracket investors hold stock in firms that pay high dividends, and high tax bracket investors hold stock in firms that pay low dividends. ${ }^{22}$ Third, dividends can increase a firm's efficiency by reducing agency costs: Distribution of dividends diminishes the internal cash flow subject to management's discretion. ${ }^{23}$ The agency-cost resolution of the dividend puzzle is the most compelling of the proferred explanations ${ }^{24}$ and will be the focus of the next Section.

19. Even when cash dividends and capital gains were taxed at the same rates (e.g., under the Tax Reform Act of 1986), the Internal Revenue Code still favored capital gains over dividends. The ability to postpone the realization of capital gains (i.e., to defer the sale of the stock) is of considerable value. See Steven V. Mann, The Dividend Puzzle: A Progress Report, 28 Q.J. BuS. \& ECON. 3 (1989).

20. Fischer Black, The Dividend Puzzle, J. PorTFolio MGMT., Winter 1976, at 5.

21. See Paul Asquith \& David W. Mullins, Jr., Signalling with Dividends, Slock Repurchases, and Equity Issues, FIN. MGMT., Autumn 1986, at 27, 35.

22. See Fischer Black \& Myron Scholes, The Effects of Dividend Yield and Dividend Policy on Common Stock Prices and Returns, 1 J. FIN. ECON. 1, 2-3 (1974); Merton H. Miller \& Myron S. Scholes, Dividends and Taxes, 6 J. FIN. ECON. 333, 334 (1978).

23. See Easterbrook, supra note 11, at 652-53 (noting possibility of "substantial divergence between [managers'] interests and those of the other participants" in firm).

24. See id.; Rozeff, supra note 11. 


\section{B. Agency-Cost Theory and Stable Dividends}

An agency relationship is a consensual relationship in which one person-the principal-employs another person-the agent-to act on the principal's behalf and subject to the principal's control. ${ }^{25}$ Given that both parties in the relationship will seek to maximize their own utility, it is reasonable to expect that conflicts of interest will emerge and that the agent will not always act in accord with the wishes of the principal. The principal can limit this divergence of interests by providing appropriate incentives for the agent and by incurring monitoring costs, i.e., supervising the behavior of the agent. Additionally, the agent can limit the divergence of interests by incurring bonding costs, i.e., promising not to take certain actions against the interest of the principal or promising to compensate the principal if he does take such actions. ${ }^{26}$ Removing the conflict of interest entirely, however, is impossible: A residual loss of welfare will always remain, even after the principal incurs monitoring costs and the agent incurs bonding costs. The "agency costs" of the separation of ownership and control are the costs incurred by principal and agent to minimize the agent's aberrant behavior and the welfare lost despite the precautions taken. ${ }^{27}$

A conflict-ridden agency relationship exists between outside shareholders (as principal) and management (as agent) in a public corporation. ${ }^{28}$ Managers have an incentive to behave in an opportunistic manner: retaining excessive earnings and investing undistributed funds ("free cash flow," in corporate law parlance) suboptimally. ${ }^{29}$ Managers have several motives for increasing the free cash flow of their firm. First, cash reserves increase their autonomy vis-àvis the capital markets. By not raising funds externally, managers avoid a capital markets inspection of their past performance and the need to persuade the capital markets of the soundness of their proposed projects. "Second, retention of earnings increases the size of a corporation, thereby increasing management's compensation, prestige, and political power. A larger corporation also facilitates managerial consumption of excessive perquisites

25. RESTATEMENT (SECOND) OF AGENCY $\$ 1$ (1958)

26. It will often be in the agent's interest to incur bonding costs. An agent will be able to command a higher wage for her services if she can credibly commit to conform her behavior to the interests of the principal.

27. Jensen \& Meckling, supra note 6. at 308

28. The intensity of the conflict depends on the ownership structure The less equily in the hands of managers and the more equity in the hands of outside shareholder, the grealer the conflet

29. See Jensen, Agency Costs, supra note 6. at 323. Michael C Jensen. The Tukeover Controners: Analysis and Evidence, in KNIGHTS. RAIDERS AND TARGETS THE IMPACT OF TIE HOSTILE TAKEOVER 314. 321 (John C. Coffee et al. eds.. 1988) (hereinafter Jensen. Tokeoters] ("Free cash flow is cash flow in excess of that required to fund all projects that have positive net present values when discounted at the relevant cost of capital. Such free cash flow must be pald out to shareholders if the firm is to be efficient and to maximize value for shareholders."); sce also O. WILJAMSSON. THE ECOVOMICS OF DISCRETIOvARY BehaVIOR: MANAGERIAL OBJECTIVES IN A THEORY OF THE FIRM 28-37 (1964)

30. See sources cited supra note 3. 
and enables management to reward middle managers with promotions. ${ }^{31}$ Third, accumulated earnings decrease the risk of bankruptcy, either by increasing the firm's equity or by facilitating the firm's acquisition of other enterprises in order to diversify away the risk of business failure. ${ }^{32}$ Unfortunately, projects financed by retained earnings have a lower return than projects financed by new issuances of debt or equity. ${ }^{33}$ The managerial preference for internal financing disregards the shareholder preference for a higher external rate of return.

The problem of free cash flow is not hypothetical. ${ }^{34}$ Nor are the costs of free cash flow negligible. ${ }^{35}$ Investors are aware of management's pernicious tendency to retain excessive amounts of earnings; investors rationally discount

31. Michael C. Jensen, Eclipse of the Public Corporation, HARV. Bus. REv., Sept.-Oct. 1989, at 61, 66 [hereinafter Jensen, Eclipse].

32. Managers' human capital is an investment in the firm that is exposed to the risk of bankruptcy. Managers can only diversify that risk through acquisitions of different firms. Managers' acquisitions for the purpose of diversification are usually suboptimal, because shareholders can diversify their risk more efficiently and do not need managers to diversify through expensive acquisitions. See Yakov Amihud \& Baruch Lev, Risk Reduction as a Managerial Motive for Conglomerate Mergers, 12 BELL. J. ECON. 605 (1981).

33. See infra note 35 .

34. See, e.g., Brent W. Ambrose \& Drew B. Winters, Does an Industry Effect Exist for Leveraged Buyouts?, FIN. MGMT., Spring 1992, at 89; Margaret M. Blair \& Martha A. Schary, Industry-Level Indicators of Free Cash Flow, in THE DEAL DECADE 99, 128 (Margaret M. Blair ed., 1993) (concluding from empirical data that "from 1982 through 1989 the U.S. corporate sector was caught up in an epidemic of free cash flow"); Kenneth Lehn \& Annette Poulsen, Free Cash Flow and Stockholder Guins in Going Private Transactions, 44 J. FIN. 771 (1989).

The conflict of interests between managers and shareholders over free cash flow is the most significant of the agency costs that large public corporations face. See HENRY HANSMANN, OWNERSHIP OF ENTERPRISE (forthcoming 1995) (manuscript at 32-34, on file with author); Jensen, Eclipse, supra note 31 , at 66.

35. A study by Baumol, Haim. Malkiel, and Quandt (BHMQ) determined that the return on retained earnings ranged from $3.0 \%$ to $4.6 \%$, on debt from $4.2 \%$ to $14.0 \%$, and on newly issued equity from $14.5 \%$ to $20.8 \%$. The range of returns exists because of various definitions of earnings and diverse assumptions about the lag between the time of investment and realization of returns. See William J. Baumol et al., Earnings Retention, New Capital and the Growth of the Firm, 52 REV. ECON. \& STAT. 345, 347-48, 353 (1970).

These results were the subject of several methodological criticisms. See R.A. Brealey et al,, The Return on Alternative Sources of Finance, 58 REV. ECON. \& STAT. 469 (1976); Irwin Friend \& Frank Husic, Efficiency of Corporate lnvestment, 55 REv. ECON. \& STAT. 122 (1973); George A. Racettc, Earnings Retention, New Capital and the Growth of the Firm: A Comment, 55 REv. ECON. \& STAT. 127 (1973); G. Whittington, The Profitability of Retained Earnings, 54 REV. ECON. \& STAT. 152 (1972).

In response to these criticisms, BHMQ performed a second study that divided the original sample of firms into two groups. The second study found that for firms issuing more than trivial amounts of new equity. the return on retained earnings $(11.2 \%)$ was in the same range as the return on equity $(12.3 \%)$ and on debt $(9.8 \%)$. For firms that issued insignificant amounts of new equity, however, the average rate of return on retained earnings was about zero. See William J. Baumol et al., Efficiency of Corporate Investment: Reply, 55 REV. ECON. \& STAT. 128 (1973). But cf. Ramaswami Murali \& Johnathan B. Welch, Agents. Owners, Control and Performance, 16 J. BUS. Fin. \& ACCT. 385, 396 (1989) (finding no evidence of differential performance between closely held and widely held firms due to differences in agency costs).

Also, studies have shown that managers tend to invest retained earnings in ventures that yield lower returns and face lower risk than those financed by new capital. The lower yield is probably due to managers' large investment in firm-specific assets. Managers' investment of human capital is less diversified than passive investor portfolios. See Edward S. Mason, The Apologetics of "Managerialism", 31 J. BuS. 1 (1958); R. Joseph Monsen, Jr. \& Anthony Downs, A Theory of Large Managerial Firms, 73 J. POL. ECON. 22I, 232-33 (1965). 
a firm's stock price to reflect the expected costs of this form of managerial opportunism. Management thereby acquires an incentive to promise investors credibly that managerial discretion over dividend policy will not be abused. ${ }^{36}$

Dividends can serve as a solution to the problem of agency costs. For instance, managers can pledge to distribute a substantial amount of dividends annually. The distributions themselves decrease funds available for suboptimal managerial investment and perquisite consumption. ${ }^{37}$ Moreover, a dividend distribution compels a firm to raise new funds in order to execute its business plans. This need for financing will expose the firm to the scrutiny of investors in the capital markets and of investment bankers and underwriters who serve as intermediaries between the firm and the capital markets. The scrutiny of participants in the capital markets will further reduce the firm's potential to make poor investments. ${ }^{38}$ In short, dividend distribution reduces agency costs.

The proposition that dividends are able to ameliorate the agency-cost problem enjoys significant empirical support. One scholar has determined that "[f]irms establish higher dividend payouts when insiders hold a lower fraction of the equity and/or a greater number of stockholders own the outside equity. This evidence supports the view that dividend payments are part of the firm's optimum monitoring/bonding package and serve to reduce agency costs." ${ }^{39}$ A host of other studies have corroborated this result. ${ }^{20}$ Notwithstanding the empirical verification, the agency-cost explanation of the dividend puzzle has a major shortcoming. Dividend payouts per se do not effectively bond management to reduce agency costs. Since dividend policy is completely within the discretion of management, managers can opportunistically reduce or omit dividend payouts at any time.

36. There are several means by which the corporate structure controls managenal opportunism the incentives embodied in managerial compensation, the montonng function performed by the board of directors, and the shareholder voting mechanism. In addition. there are forces outside the corporale structure that restrain management: the product markets, the financial markels (equily or debt). the market for managerial services, and the market for corporate control. Several of these means of control operale in concert; others operate in sequence, coming into play only as the level of inefficiency increases

37. The actual dividend payout would refiect a balance between the benefits of reducing agency costs and the costs of paying dividends. The latter include the personal tax liability imposed on shareholders and the transaction costs involved in raising new funds in the market to finance invesiments The existence of debt in the capital structure increases the costs of dividend distnbution Because dividend distribution increases bondholders' risk of default, bondholders will charge higher interest rates and thereby increase the cost of the firm's debt. Given that each firm has a different ownershp structure. and thus a different susceptibility to agency costs, each firm's optumal dividend policy is idios; ncralic See JAMES S ANG. DO DIVIDENDS MATTER? A REview OF CORPORATE DIVIDEND THEORIES AND EVIDENCE 10 (Monograph Senes in Fin. \& Econ. No. 2, 1987).

38. See Easterbrook, supra note 11 , at 654

39. Rozeff, supra note 11 , at 250.

40. See Claire E. Crutchley \& Robert S. Hansen. A Test of the Agency Theon of Managertal Ownership. Corporate Leverage, and Corporate Dividends. FIN. MGMT., Winter 1989, at 36. 37, John S Jahera, Jr. et al., Growth, Beta. and Agency Costs as Determinanis of Divdend. AKRox BLs \& EcoN REV., Winter 1986, at 55: Larry H.P. Lang \& Robert H. Litzenberger. Dudend Announcements Cash Flow Signalling vs. Free Cash Flow Hypothesis?. 24 J. FIN. ECON. 181, 190-91 (1989): Wılliam P Lloyd et al . Agency Costs and Dividend Payout Ratıos, 24 Q.J. BuS. \& ECoN. 19 (1985). 
If management could bond itself regarding the firm's dividend policy, agency costs would decline, and the share price of the firm's equity would rise. Given a credible commitment from management to shareholders to distribute periodically a certain level of dividends, the $e x$ ante reduction in agency costs (i.e., the net present value of all potential agency costs that will be eliminated by a commitment to maintain high dividend payouts) will be reflected in the current share price of equity. If, however, management is unable to make a credible commitment, the influence of dividends on agency costs would be diminished to the ex post effect of dividends already paid out. $^{41}$

Stabilizing dividend policy serves to alleviate the bonding problem. Managers generally commit themselves to distribute dividends four times per year and at a constant fraction of earnings. ${ }^{42}$ In pursuing stable dividends, though, they avoid drastic changes in dividend payments that might otherwise be dictated by drastic changes in earnings; that is, they tend to "smooth" dividend payments. ${ }^{43}$ Over time, managers can develop a reputation-for themselves and their firm-for maintaining a certain absolute level of distribution. ${ }^{44}$ The reputation achieved through a stable dividend policy is

41. At time $t_{0}$, the market discounts the stock price to reflect all future agency costs. Suppose that at time $t_{1}$ the firm enjoys accumulated eamings. Management can either inefficiently invest this cash or distribute it to the shareholders. The market is uncertain about which choice management will make. Thus, the price will be discounted to take account of the potential agency costs from time $t_{1}$ to the future and those anticipated at time $t_{0}$. If management chooses to distribute the cash as a dividend, from an ex post perspective, it avoids potential agency costs; therefore, part of the discount will disappear and the stock price will rise. Yet, if there is no bonding regarding future dividends, the price will be discounted because of potential agency costs from time $t_{1}$ to the future. This might explain the use of "special" dividends as a defensive tactic against takeovers. See generally David J. Denis, Defensive Changes in Corporate Payout Policy: Share Repurchases and Special Dividends, 45 J. FIN. 1433 (1990).

42. Ross ET AL., supra note 2 , at $522,544-45$.

43. John Lintner conducted a series of interviews with corporate managers about their dividend policies. Most of the managers thought of their dividend policies in terms of the proportion of earnings that should be paid out, rather than the proportion that should be plowed back into the firm to finance growth. They felt that shareholders were entitled to an adequate portion of the firm's carnings and that the firm should have some long-term target payout ratio. A firm that consistently adhered to its payout ratio would have to change its dividend whenever earnings changed. The managers in Lintner's survey, however, wero averse to such vacillation. They believed that shareholders favored a constant progression in dividends. Thus, even when circumstances appeared to justify a substantial increase or decrease in their firm's dividend, they made only partial moves toward their target payment. John Lintner, Distribution of Incomes of Corporations Among Dividends, Retained Earnings, and Taxes, 46 AM. ECON. REv. 97, 99-101 (1956).

Fama and Babiak went on to calculate the target ratio and alignment rate for each firm. They found that, on average. firns strive to distribute about $50 \%$ of their current net income and to move their old dividend policy about one-third of the way towards this goal each year. Eugene F. Fama \& H. Babiak. Dividend Policy: An Empirical Analysis, 63 J. AM. STAT. Ass'N 1132 (1968). For example, if a firm's payout ratio is $50 \%$ and the firm eams $\$ 120$ a year, it will pay out $\$ 60$ as a dividend. If, in the following year. the firm earns $\$ 240$ and the managers anticipate that this level of earnings will persist, the firm should pay out $\$ 120$ as dividend. The firm, however, will pay out only $\$ 80$ that year, $\$ 100$ the next year, and not until the third year will it pay out a $\$ 120$ dividend. Each year the firm will move one-third of the way towards its goal. Managers tend to apply the same strategy if earnings decline. Managers will not change their firm's dividend policy, however, to respond to what they see as temporary changes in eamings.

44. Easterbrook, supra note 11, argues that agency-cost theory explains the stability of dividends, but I do not find his reasoning convincing. Easterbrook contends that commitment to a fixed pattern of dividends, irrespective of profit fluctuations, is more likely to push a firm to the capital markets for 
fragile; consequently, financially weak firms that are unable to maintain a stable dividend policy will generally omit dividends altogether rather than frequently decrease their payout. ${ }^{45}$ On the other hand, healthy firms that can maintain a stable dividend policy are reluctant to omit dividends in the face of temporary financial distress. ${ }^{46}$ The longer the firm's record of stable dividends, the higher the firm's reputation investment, and the more valuable the firm's dividend commitment for reducing agency costs. ${ }^{47}$

In other words, while a particular dividend payout reduces agency costs by directly removing funds from the clutches of management, the stability of dividend policy signals the commitment of management to abstain from future expropriation of shareholder wealth. Consequently, as a firm's reputation for dividend stability increases, the reputation serves as an increasingly powerful bonding device and induces shareholders to attach higher value to the stock. ${ }^{48}$ Of course, managers of a firm with a strong tradition of stable dividends might still cut dividends in the future. As the reputation investment increases, however, management's potential benefit from opportunistically cutting dividends falls below the value of the squandered reputation investment. ${ }^{49}$

financing investments. Yet the mere fact that a firm sets a payout urget relaluve to carnings is equally likely to compel the firm to raise money in the capital markets. Stability of dividends explauns the phenomenon of slow managerial adjustments towards the payout target, which is inexplicable from Easterbrook's perspective. See Lintner, supra note 43, at 99-101.

On the role of reputation in assuring contractual performance, see Benjamin Klein \& Kesth B. Leffler. The Role of Market Forces in Assuring Contractual Performance. 89 J. POL ECON. 615 (1981)

45. "Financially weak firms infrequently reduce the dividend. Rather than cut the dividend. they ether maintain a stable dividend or omit it altogether." Alber Eddy \& Bruce Seifer. Dividend Changes of Financially Weak Firms. 21 FiN. REV. 419.429 (1986). The initial sample of the Eddy and Seifer study included 216 firms that had a $C$ (lowest possible) rating according to Value Lune in at least one quarter from 1978 to 1983. Id. at 421-22. Of these. 125 firms pard no dividend at all. and 16 firms made only sporadic payments. The final sample included the remanning 75 firms. Forty firms in this sample omulted their dividend during the period studied; only 10 of the firms reduced their dividend Mlost of the firms that omitted their dividend did not resume it with any dispatch. In the few cases where firms did resume payment, they did so at least two years after the omission. Id. at 424-25.

46. A study of dividend policy adjustments by 80 NYSE-listed firms in financial distress revealed that. "absent binding [debt] covenants, dividends are cut more often than omutted. suggesung that managena! reluctance is to the omission and not simply the reduction of dividends Moreover. managers of firms with long dividend histories . . view dividend omissions as particularly unattractive "Harry DeAngelo \& Linda DeAngelo, Dividend Policy and Financial Distress: An Empincal Investiganon of Troubled NYSE Firms, 45 J. FIN. 1415, 1415 (1990).

The sample included 80 NYSE-listed firms that had at least three annual losses between 1980 and 1985. These firms reported very few losses in the 10 years before the onset of financial trouble. Id. at 1416 "[O]ur sampling algorithm predominantly identifies firms that were healthy pnor to their initial annual loss during 1980-1985. ... In shor. our sample consists primarily of large. Hell-known indusinal firms that were adversely affected by the economic downtum of the carly 1980s." Id. at $1+117$

47. See id. at 1415.

48. This phenomenon explains why share repurehase plans cannot replace dividends. Mlanagement can time share repurchases to redound to its advantage. A stable repurchase plan is not feasible, and thus cannot effectively bond management. See Michael J. Barclay \& Clifford W'. Smith. Jr. Corporate Payout Policy Cash Dividends Versus Open-Market Repurchases. 22 J. FIN. ECON 61.65 (1988)

49. That is, the effect on managers of the resulting drop in the stock pnce would be greater than the potential agency costs resulting from the dividend cut. i.e.. excess perquisites and subopumal investment 
The agency-cost explanation of the dividend puzzle is both theoretically and empirically convincing. It explains why managers distribute dividends even in the face of high nonagency costs. ${ }^{50} \mathrm{~A}$ stable dividend policy is a powerful management-made bond against abuse of discretion in the use of accumulated earnings. But are stable dividends the best device for reducing agency costs? Legislators have available to them a range of alternatives for reducing the adverse effects of expansive managerial discretion. At one extreme, corporate law might give management unbounded discretion, subject only to the supervision of the takeover mechanism. At the other extreme, corporate law might encourage managers to regulate themselves by employing debt financing, which constrains managerial discretion by forcing the continual payout of accumulated earnings in the form of interest. Between these two extremes there are alternatives that shift only some of management's discretion to shareholders-e.g., through periodic shareholder voting or option mechanisms. ${ }^{51}$ For instance, corporate law might accord management discretion over how to invest retained earnings but shift to shareholders the decision of how much earnings to retain. This shareholder dividend discretion might require shareholders to vote as a group or might provide shareholders with an individual option. The efficiency of these alternatives will be assessed below.

A stable dividend policy has costs and benefits. As we have seen, on the benefit side, a stable dividend policy reduces agency costs and enhances a firm's value. On the cost side, continually raising new funds in the capital markets is expensive ${ }^{52}$ and shareholder tax liability for the perpetually maintained dividend payout is high. Additionally, as a firm's reputation investment in dividend stability increases, its dividend policy becomes more inflexible. Anxious to protect their reputation for consistency, managers will be reluctant to cut dividends even when financial difficulties arise. ${ }^{53} \mathrm{~A}$ dividend cut would lower the firm's stock price by an amount greater than the decrease in firm value caused by poor business performance, as the price drop would reflect the loss of the reputation investment as well. Similarly, managers will be reluctant to make justified dividend increases, because such increases cannot be rolled back in the future to reflect lower business performance without the risk of reputation loss. Both upward and downward dividend

50. See Jean Crockett \& Irwin Friend, Dividend Policy in Perspective: Can Theory Explain Behavior?, 70 REV. ECON. \& STAT. 603, 610 (1988) ("[A]ny resulting reduction of agency costs provides a true rationale for (after-tax) dividend preference, other things equal.").

51. Another intermediate alternative is that of incentive compensation plans. While these plans are effective in reducing agency costs to the extent that they produce management ownership of the firm, they also destroy the benefits of separating ownership from control pro tanto. See, e.g., Dennis W. Cariton \& Daniel R. Fischel, The Regulation of Insider Trading, 35 STAN. L. REV. 857, 869-70 (1983); John C. Coffee, Jr., Shareholders Versus Managers: The Strain in the Corporate Web, 85 MiCH. L. REv. 1, 16-24 (1986).

52. See Jay R. Ritter, The Costs of Going Public, 19 J. FIN. ECON. 269 (1987).

53. See supra notes $45-46$ and accompanying text. 
inflexibility will create opportunity costs and lead to a suboptimal investment policy.

\section{Alternatives to Stable Dividends for Reducing Agency Costs}

\section{The Takeover Mechanism}

If management performs inefficiently - consumes excessive perquisites and invests suboptimally-its actions will eventually be detected by the capital markets, leading to a price decline and possibly to a takeover attempt. The ever-present threat of a hostile takeover might cause management to invest an optimal amount of retained earnings and to consume reasonable amounts of perquisites. ${ }^{54}$ What do dividends add?

A takeover is a very expensive transaction. The costs to the bidder include the bid price needed to induce target shareholders to tender their shares, and sizable search and bidding expenses. ${ }^{\text {ss }}$ Additionally, bidders incur high transaction costs, often disregarded by corporate law scholars, in achieving effective control over the firm after the transfer of ownership is completed. ${ }^{\text {so }}$ Managers are free to deviate from efficient performance as long as they do not cause a price decline that exceeds the costs of a takeover. ${ }^{57}$ In fact, managers can safely allow the decline in the price of their firm's equity to exceed a prospective raider's acquisition expenses, because a raider contemplating a takeover would compare his certain costs against his expected value from the takeover. Because there is always a risk regarding the success of a tender offer, a raider will only launch a hostile takeover if the expected value of the takeover attempt (the mismanagement discount on the target's equity multiplied by the acquirer's chance of success) is greater than the acquisition expenses. In recent years, increased use of defensive tactics and the adoption of state antitakeover legislation have significantly reduced the probability of succeeding in a takeover attempt. ${ }^{58}$ These developments have increased the costs and

54. See Robert Charles Clark, CoRporate LAW $\$ 14.1$, al 599 (1986).

55. See Gregg A. Jarrell \& Michacl Bradley. The Economic Effects of Federal and Siate Regulatuons of Cash Tender Offers, 23 J.L. \& ECON. 371.373 (1980) (estumatung average costs of takeover to be as high as $73 \%$ of pretakeover price); Gregg A. Jarrell et al. The Market for Corporate Control The Empirical Evidence Since 1980, J. ECON. PERSP.. Winter 1988. at 49. 51-52 (notung that vanous studies have found target premiums in early 1980's to range from 19\% to 30\%) If there are several bidders, the costs of a takeover attempt are even greater.

56. Oliver E. Williamson, Corporate Control and Business Beiavior 99 (1970).

57. See Peter Crampton \& Alan Schwartz, Using Auction Theory To Inform Takeover Regulation. 7 J.L. ECON. \& ORganization 27, 30-31 (1991): Alan Schwarz. Search Theory and the Tender Offer Auction, 2 J.L. ECON. \& ORGANIZATION 229 (1986).

58. See MERgERS AND RestrUCtURING, supra nole 16. at 481-526. 546-19, Robern Romano. The Political Economy of Takeover Statutes, 73 VA. L. REv. 111. 112 (1987): Stout. supra notc 2. at 691. see also Jarrell \& Bradley, supra note 55, at 373-74 (arguing that Williams Act and state antitakcover stalutes increase costs of takeovers by mandating disclosure of information and delaying acquistlions) 
risks of takeovers, expanding incumbent management's latitude to perform inefficiently. ${ }^{59}$

Dividend distribution is a comparatively cheap device for deterring managerial opportunism. Although substantial dividend payouts do compel firms to incur the transaction costs of raising new funds to finance future investment and do force shareholders to pay more in taxes, ${ }^{60}$ these costs to a firm are low in comparison with the inefficiencies permitted by the frictionimpaired market for corporate control. ${ }^{61}$ In short, dividends are better at reducing possible managerial inefficiency. ${ }^{62}$

Dividends have an additional advantage over takeovers in their ability to ensure efficient performance. While takeovers are triggered only after management has made an inefficient investment or has consumed excessive perquisites, dividend payouts lead to a serious review of management's strategy as it attempts to raise new funds-before managers act in a selfserving fashion. ${ }^{63}$ The takeover mechanism is an ex post response to inefficient investment; even when a takeover is successful, it cannot retrieve all the waste caused by suboptimal investment. A new management can terminate a bad investment, but it cannot reimburse a firm for money already spent in undertaking the investment (i.e., sunk costs). Additionally, a takeover cannot compensate for the opportunity costs sustained during the period when managers undertook the suboptimal investment. The takeover premium reflects only what can still be saved by restoring efficiency.

On the other hand, dividend distributions reduce funds available for excessive perquisite consumption and inefficient investment, and force firms to finance new projects by raising funds on the primary market. Primary market evaluations of the profitability of new projects include a careful scrutiny of the firm's past and current performance. ${ }^{64}$ This scrutiny (and its anticipation by management) has the potential to improve the firm's overall

59. Commentators have suggested that the market for managerial services and the product markets will restrain managerial opportunism. See Eugene F. Fama, Agency Problems and the Theory of the Firm, 88 J. POL. ECON. 288, 292-95 (1980); Eugene F. Fama \& Michael C. Jensen, Separation of Ownership and Control, 26 J.L. \& ECON. 301, 307-11 (1983). In the absence of takeovers, however, the market for managerial services will not be very effective. Product markets provide little discipline in new industries and in activities that yield substantial economic rents. See Jensen, Takeovers, supra note 29, at 322. Moreover, the products market will not be very effective if the firm earns at least zero profits. See Fox, supra note 9 , at 143-50.

60. Costs of the public issuance of new securities include sizable underwriting, legal, accounting, and printing expenses. The Securities Act of 1933 imposes additional costs on an issuer: disclosure dutics, potential liability for both the issuer and its directors and top management, and increased underwriter fees to compensate underwriters for potential liability. See Fox, supra note 9, at 339-58.

61. Clark submits that any differential rate of return between projects financed by retained earnings and those financed by new equity might reflect the relative costs of market discipline through takcovers and new issues. See CLARK, supra note 54, at $600 \mathrm{n} .10$; see also supra note 35.

62. See CLARK, supra note 54, at 599-600.

63. See id. at 600 n.9.

64. See Fox, supra note 9, at 107-09. 
performance: past investments, current investments, and new investments. ${ }^{\text {as }}$ Primary market monitoring improves a firm's efficiency by reducing management's expropriation of shareholders. Sizable dividend payouts, therefore, can save a firm the costs of both bad investments and a consequent takeover.

Market review of management's prospective strategies does, in a way, restrict management's business discretion. The advance review of new issues, however, is generally performed by professional investors: investment banks and other sophisticated financial institutions. ${ }^{66}$ Most banks have a significant reputation investment to safeguard; consequently, their opinion on the quality of an issuing firm's business strategy is properly motivated. Sometimes banks serve as the underwriters of new issues; consequently, they often have a financial investment to protect as well. ${ }^{67}$ Indeed, the capital markets will consistently do better than management in assessing the value of potential investment projects. ${ }^{68}$

The investors who evaluate management's strategy in advance-when deciding whether to buy stock in a new issue-are the same investors who indirectly trigger the takeover mechanism by selling a firm's stock after assessing management's strategy. Nevertheless, dividends have a major disadvantage as a disciplinary mechanism relative to takeovers. While the takeover threat applies indiscriminately to all firms, dividend policy bonds only those managers who choose to adhere to a stable dividend policy. If managers want to expropriate shareholder wealth, they can at any time reduce dividend distributions and finance new investment with retained earnings. Acting in this way, management can isolate itself from the discipline of the primary capital markets. The higher the potential for expropriation of shareholder wealth in a given firm's ownership structure, the more likely it is that managers will take advantage of their principals. ${ }^{69}$

65. See supra note 35 .

66. Investors evaluate business plans either when they are first announced or later when they are undertaken. The average investor's opinion is reflected in the stock price. Both the assumpuon of an efficient market and the fact that an average of several forecasts is better than a single prediction suggest that the market will not do worse than management. For a discussion of efficient markets and the predictive value of average forecasts, see Ronald J. Gilson \& Reinier H. Kraakman. The Mlcchanisms of Market Efficiency, 70 VA. L. REV. 549. 581 (1984).

67. Id. at 613; see also Reinier H. Kraakman, Corporate Labilty Strategtes and the Costs of Legal Controls, 93 YALE L.J. 857, 888-96 (1984); Reinier H. Kraakman. Gatekeepers: The Anatomy of a ThirdParty Enforcement Stralegy, 2 J.L. ECON. \& ORGanization 53 (1986).

68. See Fox, supra note 9 (presenting analysis of relative advantage of captal markets over management of management-controlled firms in selecting investments): see also supra note 35 .

69. Several findings support this view. First, capital markets supply a relatucly small portion of the funds that U.S. corporations need for capital expenditures. Most funds for new investment come from retained eamings and depreciation reserves. See BAUMOL supra nole 3. al 67-69: GoRDON DONALDSON. MANAGING CORPORATE WEALTH 43-46 (1984); supra note 2. Second, the divergence between shareholders and management is reflected in differences in rate of return between owner-controlled (high retum) and

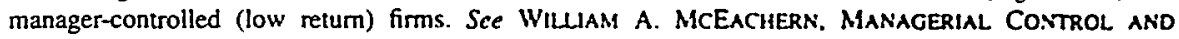
PERFORMANCE 21-56, 111 (1975) (surveying empirical studies and concluding that "owner-controlled firms provided higher average retums to shareholders than manager-controlled firms"): John R. McKean \& John 
Agency-cost theory predicts, however, that shareholders will discount the risk of expropriation and thereby provide management with incentives to abstain from such behavior. Agency-cost theory is a perfect-foresight model-it assumes that shareholders are always able to predict agency costs fully. Reality does not support an assumption of perfect foresight. The market is replete with occasions for managerial opportunism. The most notable evidence of the market's failure to detect managerial opportunism is the prevalence of takeovers that attempt to economize on agency-cost inefficiencies. ${ }^{70}$ Put differently, there are some inefficient firms in the market whose managers are free, within the limits set by the takeover market, to avoid bonding through the use of stable dividend policy.

Stable dividend policy is not the most efficacious of bonding mechanisms. A stable dividend policy retards managerial abuse of discretion better than does the takeover mechanism only for those firms that choose to bond themselves, i.e., firms pursuing efficiency.

\section{Debt Financing}

Another method management can use to bond itself to reduce agency costs is debt financing. Debt reduces agency costs in three ways. First, a firm whose capital structure is dominated by debt has committed its cash flows to making interest payments. Because managers have less discretion over payments on debt than over dividends, increased debt reduces managerial discretion over the allocation of free cash flow. ${ }^{71}$ Debt bonds managers to distribute free cash flow as interest. ${ }^{72}$ Second, the penalty for defaulting on interest payments is bankruptcy, a fate that portends grave consequences for management. The bankruptcy risk further encourages efficient performance. Third, debt generates

J. Kania, An Industry Approach to Uwner-Manager Control and Profit Performance, 51 J. Bus. 327 (1978) (presenting theories and conflicting evidence). Third, firms with a higher percentage of managers on the board (a gauge of separation of control from ownership) retain a higher percentage of earnings. See O.E. Williamson, Managerial Discretion and Business Behavior, 53 AM. ECON. REV. 1032, 1047-51 (1963). These findings together suggest that a significant number of firms opt not to use dividends as a device for reducing agency costs, and that this tendency increases as ownership separates farther from control.

70. The literature regarding takeovers suggests many motives for acquisitive activity; among these is reducing agency costs. See, e.g., Jensen, Takeovers, supra note 29, at 321-22 (attributing takeover activity to manager-shareholder conflicts over free cash flow).

71. Two articles have recently presented complementary models of free cash flow. In both, inanagcrs and investors disagree over operating decisions. The model proposed by Harris and Raviv assumes that managers want to continue the firm's current operations even if shareholders prefer liquidation. See Milion Harris \& Artur Raviv, Capital Structure and the Informational Role of Debt, 45 J. FIN. 321, 324-25 (1990). Debt mitigates this problem by granting investors (bondholders) the option to force liquidation if cash flows are poor. The Stulz model assumes that managers want to invest all available funds even if distributing dividends is better for investors. See René M. Stulz, Managerial Discretion and Optimal Financing Policies, 26 J. FIN. ECON. 3, 5-8 (1990). Here debt mitigates the problem by forcing interest payments and reducing free cash flows.

72. Michael Jensen argues that managers ought to achieve high levels of bonding by having their firm assume a high level of debt. See Jensen, Takeovers, supra note 29, at 322-23. 
valuable information about the firm that is often useful for assessing management's decisions. ${ }^{73}$

Debt financing has benefits. The bonding effect of debt can improve firm efficiency. Debt brings default early in the path of declining efficiency-before inefficient or self-serving managers destroy much of a firm's value. Debt possesses a tax advantage over dividends. ${ }^{74}$ Debt financing also has costs. Debt distorts a firm's investment policy. Debt reduces a firm's resiliency because interest payments are less flexible than dividends. This inflexibility could cause either suboptimal managerial risk taking ${ }^{75}$ or an inordinate resort to wasteful bankruptcy proceedings. ${ }^{76}$ Moreover, the issuance of debt securities involves transaction costs, increased costs due to the risk of bankruptcy, ${ }^{77}$ and opportunity costs resulting from constraints introduced in bond indentures. ${ }^{78}$ Debt financing generates its own set of agency costs as well: Bondholders face the risk of expropriation by shareholders who might engineer a shift to riskier investments or a dilution of debtholders' priority through an asset transfer to shareholders. ${ }^{79}$ Bondholders compensate themselves for these agency costs by charging higher prices for their loan of capital, thus increasing the cost of debt financing.

73. "First, the mere ability of the firm to make its contractual payments to debiholders provides information. Second. in default management must placate creditors to avoıd liquidatıon, etther through informal negotiations or through formal bankruptcy proceedings. This process. although cosily, disserminates considerable information to investors." Hams \& Raviv. supro note 7I. at 321

74. Corporations receive no deduction for profits pald out to sharcholders in the form of dwidends Corporations receive a full deduction for profits pand out to bondholders and other creditors in the form of interest. I.R.C. $\$ 163$ (1994). The Imponance of this advantage is debated Sec MlERGERS AND RESTRUCTL'RING, supra note 16, at 406-07, 412: J Fred Weston, What MiM Hate Wrough, Fis MGiT. Summer 1989, at 29, 34-36.

75. Managers have an undiversified asset-specific investment in the fim-human capital-that produces risk-averse investment decistons. Because high leserage increases the nshiness of managers' human capital investment. due to the higher potental for banhrupicy. signitieant debt will cause managers to be even more conservative in their investment decistons See Jensen \& Mechling. supra note 6 , al 349-50, 352-53. Similarly, as leverage increases. managers tend to invest more in assets that afe capable of serving as a pledge for debt, whether or not efficiencs dictates that the fim invest in such assets See Moshe Kim \& Vojislav Maksimovic. Debt and Inpu Misallocation. 45 J Fix 795. 814-15 (1990) Debt can also lead to a suboptimal amount of investment. See Elszar Bertovitch \& E Han Kim. Finanusal Contracting and Leverage Induced Over- and Under-Investment Incentues. 45 J Fis 765. 765 (1090), Clifford W. Smith, Jr. \& Jerold B. Warner, On Financial Coniracing An Analysis of Bund Cot entunis. 7 J. FIN. ECON. 117, 119 (1979) arguing that oppontunty costs imposed by debt coicnants could lead to suboptimal investment).

76. See Mark B Baribeau, Leverage Risk in the Nemfintenctul Corporate Sccior. 24 BLS Ecor 34. 36-39 (1989) (arguing that leverage nsk in nonfinancisl corporate sector is nung and is high enough to cause above-average financial distress among firms should cash flow frum current operahtons or asuet sules be jeopardized during economic downturn)

77. See, e.g., Jongmoo Jay Chol et al., Optumum Corporate Loverage wuh Rishy Debt A Demund Approach, 12 J. FIN. RES. 129, 137-39 (1989); Sieuan C. Myers, The Capial Siructure Püتlc. 39 J. Fiv 575 (1984). This risk reduces the value of equity clams and increases the pnce of debt. for example. through increased interest rates.

78. See Smith \& Warner, supra note 75 . at $125-47$

79. See Jensen \& Meckling, supra note 6, at 334-37. Additionally. if the firm has discretionan investments, managers may forgo those investments that primanly benefit bondholders See Stewar $C$ Myers. Determinants of Corporate Borrowing. 5 J. FIN. ECON 147. 149 (1977) 
The cost of debt varies among firms according to their size, amount of tangible assets that could serve as collateral, reputation, riskiness of business activity, control and ownership structure, and field of industry. For some firms, maintaining a significant degree of leverage is impractical. These firms cannot use debt as a permanent bonding device. Moderate leverage is less expensive, but it does not effectively bond management-it accords management enough leeway to perform inefficiently but not default on the debt. Ironically, although high leverage is more expensive than moderate leverage, it does not have much greater bonding power than moderate leverage: Bondholders are reluctant to exercise their right to file for the bankruptcy of their debtor, both because default then becomes a very likely consequence and because they have a high stake at risk. ${ }^{80}$ In this respect, the "privatization of bankruptcy" reduces the bonding effect of debt. ${ }^{81}$

The improved efficiency resulting from debt financing often has little to do with the debt itself. The increased efficiency is frequently the result of "privatization," i.e., concentration of ownership. ${ }^{82}$ Debt financing enables a group of entrepreneurs, such as a leveraged buy-out (LBO) partnership, to gain control of a firm and concentrate its ownership. Tight control over the firm enables owners to monitor management's performance better and to reward management in accordance with that performance, through the mechanisms of promotion and discharge. Increased concentration of control usually leads to increased efficiency. The fact that debt frequently facilitates the transfer of control causes some observers to mistake the effects of concentrated ownership for the effects of debt financing. Very high leverage is used as a temporary device to achieve control and efficient operation of a firm. Once the LBO partnership has accomplished these goals, the firm's management immediately reduces the firm's debt obligations. ${ }^{83}$ The transience of high leverage suggests that high levels of debt are not effective as a permanent bonding device.

80. In fact, very high leverage transforms debt into "equity." If any management is to perform efficiently, it must take the same risks as it would take under full equity financing. If management does not reduce the riskiness of its investments in the face of high leverage, the risk of defaulting on the debt will be high. If management invests conservatively, the firm's profitability will plummet and, again. the risk of default will be high. Bondholders recognize that efficient performance entails managerial risklaking and thus acknowledge that they should behave as equity holders. In other words, bondholders will not exercise their right to file for bankruptey proceedings in every default. Rather, the cases in which bondholders exercise their right will be similar to those in which bondholders in a firm with only moderate debt would exercise the right. Management recognizes that high leverage is not materially different from moderate debt, and the bonding effect dissipates.

81. The expression "privatization of debt" is used by Jensen to describe the practice of quick oul-ofcourt reorganizations by highly leveraged firms that get into financial trouble frequently. See Jensen, Eclipse, supra note 31 , at 72 .

82. See Jay O. Light, The Privatization of Equity, HaRv. Bus. Rev., Sept.-Oct. 1989, at 62, 62-63.

83. See Michael C. Jensen \& Kevin J. Murphy, Performance Pay and Top-Management Incentives, 98 J. POL. ECON. 225, 253 (1990) (suggesting that management buy-out transactions are transicnt devices that allow management to go private in order to adjust their package of incentives); see also MERGERS AND RESTRUCTURING, supra note 16, at 401, 408-09. 
In sum, moderate leverage has a limited bonding effect. High leverage also has a limited bonding effect, but the costs it imposes on a firm are staggering. Therefore, firms must often assume debt for reasons unrelated to bonding." While moderate leverage can achieve a particular bonding level more cheaply than can dividends, ${ }^{85}$ debt, for several reasons, is probably not better than dividends for reducing agency costs. First, bonding through debt financing is not a viable option for all firms. Firms with volatile profits or intangible assets cannot guarantee constant payment of interest or secure loans; they are thus unable to use high leverage. Second, while moderate leverage offers limited bonding, dividends can potentially bond the full earning power of the firm. Third, debt places a minimum performance requirement on management: As long as management stays above a certain threshold, it can deviate from efficiency with impunity. Shareholders will gain from the bonding effect of debt only if the minimum performance threshold is high. ${ }^{86}$

\section{Shareholder Dividend Voting}

Between the takeover mechanism and debt financing there is the alternative of shifting discretion over dividend policy to shareholders. Managers could implement this alternative in several ways. For example, they could amend the corporate charter to transfer voting rights on dividend policy matters to a majority of shareholders. Or managers could amend the charter to add a clause compelling the firm to distribute dividends on predetermined dates in amounts calculated by a predetermined formula. ${ }^{87}$ Also, the firm could issue a new class of stock with rights to vote on dividend policy. ${ }^{\text {sk }}$ The use of such methods in the modern corporate world has been, to say the least, rare.

A firm that commits itself, in its charter, to a dividend policy with a predetermined dividend payout ratio and fixed distribution dates would reduce

84. Myers' "pecking order" theory explasns that debi financing allows a firm to strike the proper balance between asymmetric information costs and financial distress costs See Mfyers, supra note 77 , at 581-85. A firm might also assume debt in order to facilitate the transfer of control.

85. See supra text accompanying notes $71-74$.

86. In other words, to the extent that leverage bonds managers, it benefits shareholders by enabling the firm to obtain cheaper debt financing. The pnee of debt. however, refleets only the net present value of the potential benefits to bondholders from managenal bonding. All of the benefits to shureholders may not be reflected in the debt price.

87. I do not attempt here to analyze all possible changes to a fim's chance that could bond management to distribute dividends. Instead. I analyze only a few examples that illustratc the tenston inherent in efforts to reduce agency costs. Shareholders can reduce agency costs either by restricting their agents' discretion or by monitoring their agents. Both of these methods will produce inflexible business operations and lower efficiency. In addition to this tension, where there are numerous principals (shareholders) and agents (managers), collective action problems and pasoner's dilemmas arise.

88. Of course, each such charter amendment or new issue of spectal stock should protect agasnst future charter amendments that nullify shareholder dividend nghts without the approval of a sufficient number of shareholders. For a more elaborate discussion of opportunisuc charer amendments by corporate insiders (managers and controlling shareholders), see Jeffrey N. Gordon. The Mandaton Structure of Corporate Law, 89 COLUM. L. REV. 1549, 1573-85 (1989). 
its agency costs by preventing management from changing dividend policy for self-serving reasons. A payout ratio that achieves maximum reduction in agency costs-that is, full distribution of earnings-is not necessarily the optimal payout. Full distribution would maximize shareholders' tax liability and the transaction costs of obtaining new financing. A quick comparison of any charter-controlled distribution policy with the current practice of stable dividends reveals the disadvantage of the former. The fixed-distribution method enjoys much less flexibility than does existing stable dividend policy: It does not allow for yearly reconsideration and commits the firm to fixed distributions on fixed dates. Since business realities often justify changing the timing of a dividend payment in a given period (for example, where a temporary profitable opportunity has surfaced) or changing the payout amount, such a method imposes high opportunity costs on a firm.

Shareholder dividend voting seems more attractive. In theory, shifting the power to decide on dividend matters to shareholders should eliminate the agency-cost problem of free cash flow, because the principals themselves would make the payout decision. Moreover, shareholders would retain the flexibility needed to adjust dividend policy to business conditions. If the majority of shareholders believe that management is inefficient and that the internal profitability of the firm is lower than the rate of return available in alternative investments, they can vote to compel dividend distribution. The shareholders need never actually compel dividend distribution-the bonding effect results from the mere threat to compel distribution. ${ }^{89}$ If shareholders never demand dividends and yet always pose a substantial threat to compel dividend payout, firms might achieve a bonding effect without incurring the costs of paying stable dividends-tax liability and the transaction costs of fundraising. The profitability of the investment opportunities available to a firm would determine whether or not to distribute earnings. Optimal investment would result.

In practice, however, shareholder dividend voting suffers from a number of defects. First, frequent dividend decisions would require frequent shareholder notification and meetings. The costs to shareholders of seeking information about past and future firm performance would also be high. The voting alternative could perhaps be improved if shareholders only voted on dividend policy during the regular annual meetings. ${ }^{90}$ Although this practice

89. This threat resembles the threat to elect new management, a power that sharcholders already possess but are reluctant to exercise. Electing to receive cash dividends would be a more limited action, a power that shareholders would be more inclined to exercise for several reasons. First, less uncertainty is involved in selecting a dividend payout level than in electing a new management. Second, a wrong decision about dividends can be corrected by reinvesting in the firm. Third, the information needed for a vole over dividends is more limited than that needed to justify the replacement of management.

90. The Italian Civil Code, Company Law Section 2328(7), mandates a shareholder vote on dividend policy at every annual meeting. 6 COMMERCIAL, BUSINESS AND TRADE LAWS para. 2433 (Louis F. Del Duca \& Patrick L. Del Duca eds., 1983). 
would reduce the costs associated with voting too frequently, it would also reduce pro tanto the shareholders' ability to adjust dividend policy to business conditions.

Second, conferring voting rights on shareholders might seem to force them to forfeit the benefits of retaining management as an agent in the first place." Yet the conferral of voting rights by itself does not mandate a forfeiture: While the vote provides shareholders with an opportunity to contest the views of management, the shareholders can continue to follow management's recommendations. The more serious defect of dividend voting is that shareholders may exercise their rights to vote inefficiently due to apathy and free-rider problems. ${ }^{92}$ In fact, these problems might return to managers complete discretion over dividends. Managers would present their recommended dividend policy, and, given apathy and free-rider problems, the recommendation could generally be expected to prevail. Shareholder voting will only reduce agency costs to the extent that shareholders control the dividend decision. ${ }^{93}$

The voting mechanism, however, does bond management in ways that other mechanisms do not. The mere possibility of shareholder intervention would deter a great deal of inefficient management behavior. ${ }^{\text {gi }}$ For instance, it is conceivable that if management proposed a blatantly inefficient dividend resolution, a sufficient number of shareholders would vote against management.

Furthermore, the growing presence of large, institutional shareholders in U.S. firms will produce better voting patterns and better monitoring. ${ }^{\text {9s }}$ The logical case for the ability of large investors to reduce agency costs is clear: A shareholder's net benefits from monitoring increase as the size of her holdings increases, and a shareholder's net benefits from not monitoring (free riding or exiting) decrease as the size of her holdings increases. ${ }^{\text {\% }}$ The

91. Usually management is better informed. better sunted. and better equipped to decide a firm's dividend policy than are shareholders. But management is not always properly motivated. This is the heart of the agency problem. Granting shareholders formal decisionmaking power over dividends, even though the power is not used in practice, will reduce agency costs. See infra notes 94-96 and accompanying lext.

92. See CLARK, supra note 54, at 389-93.

93. To the extent that shareholder votes uniformly confirm management's dividend preferences, the value of dividend voting as a brnding device declines. In such a case, efficient management would have to bond itself again by always recommending a stable dividend policy.

94. In current practice. if management opts not to bond its performance through a slable dividend policy, and the corporation performs poorly, shareholders can either sell their shares or wast for a takeover. The voting mechanism creates a response that is easier to implement than a full-scale proxy fight and more reliable than waiting for a takeover. For example, in Italy. where the voung mechanism is mandalon. management proposes a payout ratio. If management's proposal fails. then each shareholder can propose

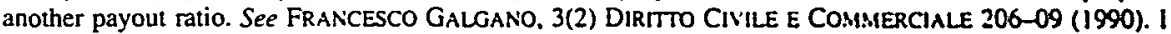
thank Edoardo Courir for his translation of, and assistance in obtanning. the Italian material.

95. See Bernard Black, Agents Watching Agents: The Promise of Institutional Investor Votce. 39 UCLA L. REV. 811, 827 (1992) ("At the end of 1990, institutions owned 53\% of the equity in U.S. public companies. up from $45 \%$ in 1986 and $38 \%$ in 1981.").

96. See Edward B. Rock, The Logic and Uncertain Significance of Instilutional Shareholder Acintsm. 79 GEo. L.J. 445, 453-63 (1991); see also Anup Agrawal \& Gershon N. Mandelker. Large Shareholders 
practical case against institutional investors is much less clear. The common anxieties about institutional investors-that they are incompetent monitors and decision makers, that they will divert corporate funds away from other shareholders, that they suffer from myopia-are largely unfounded. Institutional investors will be able to make the dividend decision: Good traders and fund managers are already skilled evaluators of corporate performance, and the dividend decision involves periodic considerations of policy matters rather than day-to-day administration of the details of a corporation's operations. ${ }^{97}$ Institutional investors will not divert corporate funds, because they are subject to fiduciary duties and public disclosure requirements, and because other institutional investors, including the corporation's management, will be monitoring their performance. ${ }^{98}$ Institutional investors are simply not very nearsighted..$^{99}$ The concentration of ownership among sophisticated financial institutions that is occurring in U.S. equity markets will ensure that shareholder dividend options are intelligently exercised.

While shifting power to shareholders by providing them voting rights would be expensive and cumbersome, it should be compared not to some ideal mechanism, but rather to the current practice of stable dividends. The costs of bonding through stable dividends include high taxes, transaction costs for new issues, and opportunity costs due to the inflexibility of dividend policy; the costs of shareholder voting include the cost of informing shareholders and opportunity costs due to the inflexibility of an annually adjusted dividend policy. Although it would be hard to make an a priori determination of which set of costs is higher, yearly voting should prove less inflexible than a predetermined long-term payout ratio. Moreover, shareholder voting has the major advantage of saving shareholders the full tax liability of maintaining a stable dividend policy and the transaction costs of new issues. These savings should prove high in relation to shareholders' costs in obtaining information.

and the Monitoring of Managers: The Case of Antitakeover Charter Amendments, 25 J. FIN. \& QUANTITATIVE ANALYSIS 143 (1990) (concluding that existence of large shareholders leads to better monitoring of managers); Harold Demsetz, The Structure of Ownership and the Theory of the Firm, 26 J.L. \& ECON. 375, 390 (1983) (finding strong link between management and owner interests in profitmaximizing behavior); Gregg A. Jarrell \& Annette B. Poulsen, Shark Repellents and Stock Prices: The Effects of Antitakeover Amendments Since 1980, 19 J. FIN. ECON. 127, 130-31 (1987) (arguing that sophisticated, well-informed shareholders such as institutions are more likely than less informed shareholders to vote in accordance with their own economic interests); Andrei Shleifer \& Robert W. Vishny, Large Shareholders and Corporate Control, 94 J. POL. ECON. 461 (1986) (arguing that owners of large blocks of shares have greater incentives to monitor managers).

On the other hand, if the interest of the large shareholder is aligned with the interest of management. then the presence of a large shareholder would decrease the effectiveness of a voting mechanism. See, e.g., John Pound, Proxy Contests and the Efficiency of Shareholder Oversight, 20 J. FIN. ECON. 237, 260-62 (1988) (suggesting that large blockholders tend to vote with management in proxy cases).

97. See Black, supra note 95 , at 852-55.

98. See id. at $855-61$.

99. See id. at 862-64; see also Ronald J. Gilson \& Reinier Kraakman, Reinventing the Outside Director: An Agenda for the Institutional Investor, 43 STAN. L. REv. 863, 863 (1991); Henry T.C. Hu, Risk, Time, and Fiduciary Principles in Corporate Investment, 38 UCLA L. REv. 277, 308-09, 314-18 (1990). 


\section{Shareholder Dividend Options}

An improved version of shareholder dividend voting might involve fixing the distribution date and the payout ratio, but rendering the actual distribution optional to each shareholder. On the fixed date, each shareholder could choose, independently of other shareholders, between receiving a cash dividend or a stock dividend. ${ }^{100}$ Exercising the option intelligently would require shareholders to monitor management's past performance and future plans.

With shareholder dividend options, as with shareholder dividend voting, it might seem that shareholders forfeit the benefits of retaining professional management. Dividend options. however, present an additional alternative to those shareholders who wish to contest management's recommendations regarding dividend policy. With dividend options, those shareholders who wish to retain the benefit of having an agent can simply follow management's recommendations. but the fate of shareholders who reject management's proposal is not determined by the will of the majority. The option system provides a dissenting shareholder with an individual right that she can exercise independently of the decisions of other shareholders.

The costs of informing shareholders under the option mechanism are equivalent to the costs of dividend voting, which, as explained above, are lower than the costs of a stable dividend policy. The problems of apathy and free riding, which are acute under the collective decision making required by the voting mechanism, are much abated by the individual decision making that the option mechanism requires. With dividend voting, the majority determines the dividend payout for all shareholders. A small shareholder should not and would not assume that her vote will be pivotal; rather, she would assume that the other shareholders will determine her fate. By contrast, with the option mechanism. each shareholder selects her own dividend payout ratio. A shareholder could invest in firm-specific information and use that information to choose what portion of her share of the firm's earnings to receive in cash and what portion to reinvest. Alternatively, the shareholder could blindly follow management's recommendation (if she trusts it) or mimic the actions of large shareholders (if she believes in their wisdom). ${ }^{101}$

The dividend option can be viewed in another way. A shareholder can influence the behavior of management either by voting ("voice") or by selling

100. Shareholder dividend options would be granted to each holder of a compration's common stoch Firms offering shareholder dividend options could include preferred stoch in their capital structure, but they need not allow holders of preferred stock to participate in the option program. To expand the scope of dividend options, a firm might provide holders of preferred stoch with a dividend option as well. A holder of preferred stock could then periodically elect to recerve cash disidends or preferred stock dividends To preserve the dividend pnority of preferred stock. the preferred dividend options must be exereised before the common dividend optuns

101. Large shareholders would find "t worthwhile to inform others aboul their decisions so as to achieve informed control over managenent. 
her shares ("exit"). Usually, voice is uttered collectively while exit is undertaken individually. In fact, the dividend option is a special alternative that is partly "voice" and partly "exit." Exercising the option requires a decision of whether or not to invest additional funds in the firm. If a shareholder opts for cash dividends, she makes a partial exit and also gives voice to her opinion concerning the profitability of the firm. ${ }^{102}$ Thus, with dividend options, unlike with dividend voting, shareholders' voice and exit are individualized.

If management has performed admirably, shareholders will opt for stock dividends, and the firm will avoid the transaction costs of a new issue. Because management will strive to persuade shareholders to opt for stock dividends, it has a strong incentive both to perform efficiently and to provide sufficient information to shareholders. With a voting mechanism, management need only persuade a majority of the attending shareholders to prevent any distribution. With the option mechanism, any unpersuaded shareholder can opt for the cash dividend. ${ }^{103}$

The dividend option for shareholders would cover all profits, and would come into play only to the extent that there are profits. Herein, however, lies the disadvantage of the option relative to debt. To the extent that debt bonds managers, it sets a minimum performance requirement. If bankruptcy is costly to managers, because they might lose the benefits of control or reputation, then debt creates incentives to work harder, consume fewer perquisites, and make better investment decisions, in order to reduce the chance of bankruptcy. ${ }^{104}$ The option mechanism, in contrast, provides no such incentive for managers to achieve a certain level of performance. If the firm has no earnings, shareholders would not receive dividend options, and management would remain undisciplined. ${ }^{105}$ The option comes into play mainly as a preventive measure: It prevents the waste of profits already earned. The option, by itself, does not compel the origination of profits.

The agency costs of the separation of ownership and control include both inefficient generation of profits and inefficient use of profits. To the extent that a firm does not bond itself against any of these risks, the market will discount the price of the firm's equity. The option mechanism would not affect firms

102. For a discussion of the mechanisms of voice and exit and their optimal mix, see generally ALberT O. HiRschman, Exit, VoICE, and Loyalty (1970).

103. Each element of the option can be modified to suit the specific needs of a firm. For instance, if fixed distribution dates produce too much inflexibility for a firm, the firm might accord discretion to management over the timing of dividends while still predetermining the full payout ratio and granting shareholders the option of receiving cash or stock dividends. Because the full payout ratio is certain. shareholders would be protected against expropriation. Management could determine dividend distribution dates based on business plans. Management would have an incentive to explain the reasons for its decision about any selected distribution date. Otherwise, the capital markets would interpret a remote date as a sign of anticipated inefficient performance and would discount the stock price.

104. See Sanford J. Grossman \& Oliver D. Hart. Corporate Financial Structure and Managerial Incentives, in THE ECONOMICS OF INFORMATION AND UNCERTAINTY 107, 130-31 (John J. McCall ed., 1982).

105. Although if the firm has no profits, the problem of free cash flow is not really a problem. 
whose inefficiency results in no profits, or only negligible profits, but other control mechanisms do affect such firms. For example, competition in product markets will, over time, drive inefficient firms out of business. Moreover, implementation of the option mechanism would probably lead firms to increase their leverage. Under the option mechanism, firms would substitute external finance, which could take the form of either debt or equity, for internal finance, which is equity. ${ }^{106}$ Dividend options would lead indirectly to increased debt financing and would thereby provide managers with incentives to achieve a certain level of performance.

On the other hand, the option mechanism will materially affect firms that generate free cash flows. Usually these are mature firms without growth opportunities. The dominant agency-cost risk in these firms is the inefficient utilization of profits that have already been earned. ${ }^{107}$ Under the option mechanism, shareholders will have control over the firm's carnings. If the investment policy pursued by management does not seem profitable, shareholders would opt for cash dividends and invest their wealth in another firm. Such control over free cash flow would substantially reduce management's capacity to make suboptimal investments and poor acquisitions. ${ }^{108}$

Providing shareholders with discretion over earnings retention through the option mechanism would reduce the agency costs of firms and improve the allocative efficiency of the economy. The option mechanism would channel resources (accumulated earnings) to their best use rather than allow them to be employed wherever generated. ${ }^{109}$ The option mechanism would also

106 See Fox, supra note 9. at 393. This claim presupposes the likely proposition that shareholders with dividend options will allow firms to retan less earnings than they do currently.

107. See supra notes $34-35$ and accompanying text.

108. The French have recognized the merits of dividend optuons French Company Law mandates an annual shareholder vote on the allocation of a corporation's profits. If the shareholders decide to distribute profits, the corporation must provide each shareholder with the option of receiving either cash or stock dividends. The shareholders power to distribute prohts is limited by a requirement that the corporation allocate $5 \%$ of each year"s profits to a "legal reserve." Even this small requirement does not obtain in those years in which the legal reserve exceeds $10 \%$ of the corporation's capital. See JEAN-PIERRE LE GALL \& Paul Morel. French Company LaW 140-41, 172 (2d ed. 1992).

109. Williamson suggested that this was the man reason for the conglomeration of firms into the multidivisıon structure (the $M-f(r m)$, in which a firm divides its corporale activities so as to permil the subunits to operate independently of each other as profit centers OUVER E. WILLAAMSON. MARKETS AND HIERARCHIES: ANALYSIS AND ANTITRLST IMPLICATIONS 136-38 (1975). The M-form organization is a response to ineffective direct capital markets discipline and the inefficiency of the taheover mechanism as a means of disciplining managements. In Willıamson's veu, the M1-form organzation is similar to a miniature capital marhet but with functions performed administraluvely by the general office rather than the actual market. Cash flows are not automatically retumed for reinvestment to the operatıng unit that generated the cash. Instead. that unit is exposed to internal competition with other projects proposed throughout the firm. and the general office assigns the cash to those projects possessing what it believes to be the best prospects. In other words, conglomeration is a means of factitating an investment of funds generated by cerrain operatıng units in projects of other units. Id. at 141-48. "In many respects, this assignment of cash flows to high yield uses is the most fundamental attribute of the Mt-form enterprise ... . Id. at 148. Enhancing the control of the captal mariets over the transfer of funds between independent firms assigns to the captal markets the role of the ultumate M-form organizition. 
maximize shareholder preferences by allowing each shareholder to select her unique dividend payout ratio and the level of discretion she wishes to provide to management.

\section{IMPEDIMENTS TO THE ADOPTION OF AN OPTION MECHANISM}

The option mechanism is an efficient means of shifting control over dividend policy from managers to shareholders. Firms inclined to provide the capital markets with such control, however, face a major impediment: tax distortion of the dividend decision. Inefficient firms, which attempt to isolate themselves from market scrutiny, find the current corporate and tax laws extremely convenient.

\section{A. Tax Distortion}

\section{The Problem}

Under the U.S. corporate tax system, cash dividends and stock dividends are taxed differently. Cash dividends are considered income to the recipient and taxed immediately at ordinary income rates, while stock dividends are exempted from current taxation and taxed at capital gains rates when the new shares are sold. ${ }^{110}$ The distinction between the taxation of the two kinds of dividend is based upon two assumptions. The first assumption is that shareholders should be taxed only after they realize a gain, either by extracting assets from the corporation or by selling shares. The second assumption is that gain from the sale of shares should be taxed favorably as a capital gain, while gain from the extraction of assets should be taxed unfavorably as ordinary income. "I Receipt of a pro rata stock dividend is not a realization event because each shareholder preserves the same proportional interest she had in the firm before the distribution. ${ }^{12}$ Thus, taxes are deferred until a realization

110. Section 301(a) of the Internal Revenue Code requires taxpayers, with some exceptions, to include in gross income "any distribution of property [including cash] made by a corporation to a shareholder with respect to its stock." I.R.C. $\$ 301$ (a) (1994). The Internal Revenue Code also declares that a taxpayer's gross income "does not include the amount of any distribution of the stock of a corporation made by such corporation to its shareholders with respect to its stock." Id. § 305(a); see also Eisner v. Macomber, 252 U.S. 189 (1920).

111. Richard B. Stone, Back to Fundamentals: Another Version of the Stock Dividend Saga, 79 COLUM. L. REv. 898, 898 (1979). Currently, the Internal Revenue Code treats capital gains favorably. I.R.C. \$ 1(h) (taxing net capital gains at $28 \%$ and taxing ordinary income in the highest tax bracket at 39.6\%). Even when tax rates on capital gains and ordinary income were equal (between 1986 and 1991). however, capital gains received preferential treatment because of the substantial benefit of tax deferral. See, e.g., Mary Louise Fellows, A Comprehensive Attack on Tax Deferral, 88 MiCH. L. REv. 722, 730-37 (1990).

112. See Eisner v. Macomber, 252 U.S. at 202-03 (holding that pro rata distribution of common stock on common stock is not taxable). The tax treatment of stock dividends derives from the realization requirement.

We are clear that not only does a stock dividend really take nothing from the property of the 
date, which is usually the day on which the taxpayer sells the shares.

The Internal Revenue Code does not treat all stock dividends with such generosity. The Code takes a "constructive receipt" approach to stock dividends payable in lieu of money. A shareholder's receipt of an option for either a cash or a stock dividend is considered a realization event even if the shareholder opts for stock dividends. ${ }^{113}$ The Code also taxes as ordinary income disproportionate stock distributions. Even in the absence of an election, if some shareholders receive a cash dividend and other shareholders receive a stock dividend, the shareholders who receive the stock dividend are taxed as if they received a cash dividend. ${ }^{114}$ These quirky aspect of the tax law would prevent a firm from voluntarily adopting an option mechanism. Granting each shareholder an option to receive either cash or stock dividends that covered all earnings would result in taxation of all earnings, regardless of how shareholders exercised their options. Full taxation of annual earnings destroys one of the most important rationales for operating a business in the corporate form. ${ }^{115}$

Under the current tax system, firms will regard granting a dividend option as equivalent to distributing cash dividends. A firm ought to distribute cash dividends only to the point at which the benefits of distribution (reducing agency costs) equal its costs (transaction costs and extra taxes). ${ }^{116}$ The dividend payout ratio of a stable dividend policy reflects such an equilibrium point. ${ }^{17}$ It is likely that the optimal payout ratio will be less than one, i.e., that a firm should distribute less than its full earnings. The proposed option mechanism over all the firm's earnings would not produce the optimal amount of distribution because it would create tax liability as if the firm distributed all of its earnings, i.e., as if the firm's payout ratio were equal to one. Any option would therefore be limited to those earnings already committed for distribution.

corporation and add nothing to that of the shareholder. but that the antecedent accumulation of profits evidenced thereby. while indicating that the shareholder is the ncher because of an increase of his capital, at the same time shows he has not realized or receised any income in the transaction.

Id. at 212. But cf. Koshland v. Helvering. 298 U.S. 41 (1936) (holding that distribution of common stock on preferred stock is taxable because class of preferred shareholders increased its interest in corporation vis-à-vis common shareholders).

113. I.R.C. $\$ 305(b)(1)$. One shareholder's receipt of a dividend option is sufficsent to deem other shareholders who receive stock dividends as extractors of assets from the firm. See Treas. Reg. $\S 305-2(\mathrm{a})(5)(1994)$.

114. I.R.C. $\S 305(\mathrm{~b})(2)$.

115. See Boris I. BITTKER \& JaMes S. EustiCE, Federal INCOME TAXation of Corporations AND SHAREHOLDERS \& 5.01[5] (1994); CARY \& EISENBERG, supra nolc 7. al 95-97.

116. In countries where dividends are not taxed more heavily than capital gains, firms adopt higher dividend payout ratios. See, e.g.. Allen J. Michel \& Israel Shaked, Couning and Indusiny Influence on Dividend Policy: Evidence from Japan and the U.S.A., 13 J. BUS. FIN. \& ACCT. 365. 380 (1986) (finding that "payout ratios of the sampled Japanese industres were higher than those of their Amencan counterparts").

117. The firm's dividend payout ratio determines the fraction of earnings that will be laxed immediately as dividends. The rest of the firm's carnings will enjoy tax deferral as stock apprectanion. 
This helps explain the increasingly widespread phenomenon of dividend reinvestment plans. ${ }^{118}$

\section{Dividend Reinvestment Plans}

In dividend reinvestment plans, firms continue to distribute stable dividends, but they also grant each shareholder the option to reinvest part or all of the dividend in newly issued shares. ${ }^{119}$ Firms offer the shares at a discount, usually five percent, ${ }^{120}$ and once the shareholder exercises the option, the firm performs the reinvestment automatically. The discount, which represents the firm's savings on the transaction costs of issuing stocks through an underwriter, partially motivates the reinvestment. ${ }^{121}$ But why, given the extra tax liability, do firms distribute dividends just to reinvest them automatically? Why do they not simply reduce the payout ratio? ? $^{122}$

Managers must preserve a stable dividend payout ratio to maintain the bonding effect of dividends. ${ }^{123}$ The purpose of granting the reinvestment option only after distribution is to limit immediate taxation to earnings already designated for distribution as dividends, that is, to exclude retained earnings from immediate taxation. The automatic reinvestment does not frustrate the ability of dividends to reduce agency costs, because each shareholder can opt out of the reinvestment plan and obtain a cash dividend based on the original

118. Corporations have been eager to adopt plans that permit shareholders to reinvest dividends into newly issued equity shares. In 1974, the first full year during which firms issued such plans, dividend reinvestment plans accounted for $5 \%$ of the total dollar value of new equity offerings. By 1982, these plans accounted for over $16 \%$ of new equity offerings. Pamela P. Peterson et al., The Adoption of New-Issue Dividend Reinvestment Plans and Shareholder Wealth, 22 FIN. REV. 221, 221-22 (1987).

119. There are two types of plans: (1) where the reinvestment purchases already-issued shares; and (2) where the reinvestment purchases newly issued shares. Some firms reserve the right to switch between plan types (original issue or open market purchase) so as to preserve the flexibility to raise new capital when necessary. See Albert J. Fredman \& John R. Nichols, Sizing Up New Capiral Dividend Reinvestment Plans, CAL. MGMT. REv., Summer 1982, at 77.

The option granted in any such reinvestment plan is not directed at the firm's retained carnings: it is given only with respect to dividends that have already been distributed. Nevertheless, this option has a similar effect-although limited to the part of earnings committed to dividends-to that of the option mechanism I consider.

120. The value of the discount is subject to taxation. See Peterson et al., supra note 118, at 224 n.7.

121. See generally Myron S. Scholes \& Mark A. Wolfson, Decentralized Investment Banking: The Case of Discount Dividend-Reinvestment and Stock-Purchase Plans, 24 J. FiN. ECON. 7, 7-9 (1989) (questioning efficient market hypothesis on ground that authors made profit on purchases of discount stock).

122. The answer to this enigma evaded Scholes and Wolfson:

It is puzzling that firms are willing to incur such high costs to pay dividends and then issue an offsetting amount of new equity. Not only is there the familiar tax cost of paying dividends, but here we also have the administrative cost of running the discount program, the transaction costs associated with resales of shares in the secondary market, and perhaps most important, the cost to existing shareholders of offering $5 \%$ discounts to new shareholders. Although the answer may relate to concern over adverse stock-market responses to cutting dividends or floating an equity issue through an underwriter, these phenomena are not well understood and deserve closer attention.

Jd. at 29.

123. See supra text accompanying notes 41-49. 
stable dividend payout ratio. The shareholder threat to opt out of the plan provides managers with an incentive to perform in the shareholders' interests. ${ }^{124}$ If management decided instead to retain more earnings, through direct reduction of the dividend payout ratio, shareholders would be unable to restore the original payout ratio when faced with inefficient managerial performance. Consequently, investors would discount the stock price to reflect the increased potential for agency costs, regardless of the firm's actual performance.

The proposed dividend option mechanism would have effects similar to those of a dividend reinvestment plan that covered all of the firm's earnings. Annual shareholder dividend options would be equivalent to a dividend reinvestment plan that fully distributed earnings every year. "2" The option mechanism would also have the same tax consequences as a reinvestment plan that fully distributed a firm's earnings. Under the current tax system, even if all shareholders opted for stock dividends, the option would be treated as if the firm had fully distributed its earnings and shareholders had subsequently reinvested the earnings back into the firm. Shareholders would be taxed currently at ordinary income rates to the extent of their pro rata share of the firm 's earnings. ${ }^{126}$

The above analysis explains why firms adopt reinvestment plans-namely, to increase retention of earnings while preserving a stable dividend payout ratio. A firm's optimal dividend payout ratio, where the costs and benefits of dividend distribution are equal, is likely to be less than one. Switching to the option mechanism and its full-distribution requirement would force upon a firm the suboptimal payout ratio of one and the current taxation of full earnings at ordinary income rates.

Therefore, a firm is unlikely to switch voluntarily to an option mechanism. Under the current tax system, the switch would increase taxes for the firm's shareholders and cause shareholders to demand a higher return, i.c., to discount the stock price. The decrease in stock price would be substantial because it would reflect the present value of all future taxes. ${ }^{127}$ In comparison, other

124. The adoption of a dividend reinvestment plan signals that a firm is performing well A firm that adopts such a plan is more effici"nt because it maintains the bonding effeet of dividends. This reasoning can explain Scholes and Wolfso., finding that a group of firms offenng discount stock-purctuase plans outperformed a comparable group of firms that did not offer such plans. Scholes $\&$. Wolfsun. supra notc 121, at 24-27. But see Peterson et al.. supra note 118. at 228-31 (examining reaction of secunly prices to adoption of new-issue dividend reinvestment plans and observing no significant market reaction for nonutility corporations).

125. The option mechanism I propose would have some subile supenonties to dividend reinvestment plans. First, the option mechanism reduces transaction costs by cnablıng a firm to reınvest eamıngs without an initial distribution of dividends. Second, and most important. the adoption of a dividend reinvestment plan is within the discretion of management-exposing shareholders to agency costs-while the option mechanism would be mandatory. See infra par III.

126. See supra part II.A.1.

127. On the concept of discounts due to taxes, see. e.g. Alan J. Auerbach. Wealth Martmization and the Cost of Capital. 93 Q.J. ECON. 433 (1979) (discussing effects of capital income taxes on behavior of 
firms could offer investors a higher return by adhering to their original payout ratio. Unless the benefits from full distribution offset the costs of additional taxes, firms are without an incentive to switch voluntarily to an option mechanism.

The existence of dividend reinvestment plans exhibits that some firms are ready to transfer control over the earnings reinvestment decision to the capital markets, but that, due to a tax distortion, the scope of such a shift is limited to earnings already designated for distribution. Any endeavor to pave the way for efficient firms to shift control over their full accumulated earnings to the capital markets should begin by removing the tax distortion. To remove the tax distortion it will be necessary to equalize the tax consequences of stock dividends received upon exercise of an option and stock dividends received willy-nilly.

\section{B. Removing the Tax Distortion}

Several tax reforms could equalize the tax consequences of stock dividends received upon exercise of an option and stock dividends received willy-nilly. For the purpose of facilitating a shift of control over dividend policy, each reform alternative is effective. Each alternative is controversial, however, for various tax policy reasons.

\section{Taxing an Option Based on Its Actual Exercise}

The first alternative, which is the simplest and the least drastic, is to delete the rules that tax stock dividends upon receipt in an election or in a disproportionate stock distribution. ${ }^{128}$ In the wake of this reform, only shareholders opting for cash dividends would be taxed immediately; those opting for stock dividends would enjoy tax deferral and perhaps capital gain treatment. Stock dividends received upon exercise of the option would be treated the same as stock dividends received willy-nilly (and the same as stock appreciation). ${ }^{129}$

The Internal Revenue Code's treatment of elective dividends and disproportionate stock distributions cannot be justified on tax policy grounds.

firms).

128. While this reform clearly entails the excision of $\S 305(b)(1)$ and (2), it also entails the removal of the remaining provisions of $\S 305(\mathrm{~b})$. This should not raise any eyebrows because the remaining provisions of $\S 305(\mathrm{~b})$ are variations on the theme of disproportionate stock distribution.

129. In 1980, lobbyists attempted to tax dividend reinvestment plans based upon a shareholder's actual exercise of the option; that is, to defer taxation of dividends received but reinvested. Congress introduced a limited version of this change in 1981. Under the Economic Recovery Tax Act of 1981, those shareholders of "qualified utilities" who participated in a reinvestment plan were able to exclude up to $\$ 750$ from their taxable income. Congress designed this provision to have no effect on dividends reinvested after 1985. See Peterson et al., supra note 118, at 224. 
The realization requirement counsels against the taxation of all stock dividends, and neither the constructive receipt doctrine nor disproportionality entails the diverse treatment of stock dividends. If the realization requirement insists upon the deferral of taxation on mere stock appreciation, then receipt of stock dividends upon the exercise of an option should not be deemed a realization event. The realization requirement has three common justifications. ${ }^{130}$ First is the uncertainty-of-profits argument: Because stock prices are volatile, a taxpayer cannot certainly capture profits until she liquidates her investment. ${ }^{131}$ Second is the liquidity argument: If a taxpayer's resources remain tied up in her investment, she has insufficient funds with which to pay taxes until she liquidates the investment. ${ }^{132}$ Third is the valuation argument: Without a market transaction, the value of a taxpayer's accession to income must be estimated by an ill-equipped court or auditing authority. ${ }^{133}$ Given these strong justifications for the realization requirement, why is an option for cash or stock dividends taxed to a shareholder who selects stock dividends?

The conventional answer is that once such an option is granted, the shareholder receives a claim over a portion of the firm's earnings, which she can choose to collect in cash. If a shareholder opts for a stock dividend, the law treats her as if she received cash dividends and reinvested the funds. The uncertainty of profits, the ability to pay, and the valuation arguments are inapplicable to this shareholder, and the stock dividend is therefore taxed immediately.

The logic of the conventional answer, however, proves too much-it erodes the difference between stock dividends and stock appreciation. In the ultimate analysis, what makes the dividend option a realization event and stock appreciation not a realization event is the specified exercise date of the former. The specificity of exercise date, in itself, however, does not justify the tax distinction between stock appreciation and stock received from a dividend option. If a particular stock has been a bad investment, a shareholder will generally sell the stock and enjoy capital losses. If the stock has been a good investment, a shareholder is likely to hold on to the stock and pay tax later on

130. See William A. KLein \& Joseph Bankmian, Federal INCOME Taxation 298-30I (9th ed. 1993).

131. See Douglas A. Kahn. Accelerated Deprectation-Tax Expenditure or Proper Allowance for Measuring Net Income?, $78 \mathrm{MiCH}$. L. REV. 1, 48-53 (1979) (arguing that uncentanty of profits makes taxation grossly unfair).

132. See William D. Andrews, A Consumption-Type or Cash Flow Personal Income Tax, 87 HaRV. L. REV. 1113, 1143 (1974).

133. Id. at 1141-42. Many have recognized that these arguments do not hold regarding publicly traded stocks. See, e.g., David J. Shakow. Taxation Without Realization: A Proposal for Accrual Tuxation. 134 U. PA. L. REv. 1111, 1128, 1132-33 (1986): David Slawson. Toxing as Ordinar Income the Appreciation of Publicly Held Stock, 76 YALE L.J. 623, 626 (1967); Jeff Simed. Penodictry and Accretion Taxation: Norms and Implementation, 99 YALE LJ. 1817. 1866-67 (1990): Victor Thuronyi. The Taxarion of Corporate Income-A Proposal for Reform, 2 AM. J. TAX POL'Y 109. 126-27 (1983): Mark L Loure. Note. Realizing Appreciation Without Sale: Accrual Taxation of Capulal Gains on Marketable Secunties. 34 STAN. L. REV. 857, 865 (1982). 
the capital gain. To be consistent, the shareholder who retains her stock should be treated as if she extracted part of the firm's assets and reinvested the proceeds in the firm. ${ }^{134}$ The sole difference between a dividend option and the "option" facing a shareholder who has enjoyed stock appreciation is that the former has a specified exercise date and the latter does not. ${ }^{135}$ This technical difference does not justify the vastly disparate treatment the two phenomena receive under current law.

Moreover, the doctrine of constructive receipt is not sufficient to justify taxing stock dividends received under a dividend option. The doctrine is usually applied in two sets of circumstances: (1) where a taxpayer has the inalienable right to receive income on a certain date but delays receiving the income in order to defer taxation; and (2) where a taxpayer who earns income attempts to assign the income to another person in a lower tax bracket. Constructive receipt is usually applied to prevent taxpayers from manipulating the graduated rate structures. ${ }^{136}$ These paradigmatic concerns are not present in the setting of dividend options. Furthermore, the Code frequently does not impose a tax penalty on taxpayers who choose to receive a nontaxable benefit rather than a taxable benefit. ${ }^{137}$

Providing shareholders with the option to elect either a cash or a stock dividend will increase the proportional interest in the firm of those shareholders who elect stock dividends. This undeniable fact should not be the stuff of which tax distinctions are made. ${ }^{138}$ Congress' stated goal in taxing disproportionate stock distributions was to preserve the taxability of elected stock dividends. ${ }^{139}$ The weaknesses of this goal are detailed in the preceding paragraph. More important, taxing disproportionate stock distributions currently and as ordinary income is anomalous: The Internal Revenue Code treats other similar transactions quite differently. The Code is filled with statutory exceptions that permit taxpayers to transform significantly the nature and

134. Consider two shareholders. Shareholder A purchases shares of stock and enjoys an option to receive either cash or stock dividends, to be exercised on December 31. Shareholder B purchases shares without such an option. Shareholder $A$ is taxed even if she opts for a stock dividend; shareholder $B$ is not taxed. Yet, in effect, Shareholder B enjoys the very same choice on December 31: She can receive the equivalent of a cash dividend-by selling part of her shares and realizing the profits-or a stock dividend, by simply retaining the earnings. Her decision not to sell part of her shares is equivalent to Sharcholder A's opting for stock dividends. Since the same economic reality faces each sharcholder, a tax distinction between the shareholders is unwarranted.

135. As far as the arguments supporting the realization requirement for stock appreciation are concerned, it should be irrelevant that one shareholder receives cash from the firm's earnings while another receives cash from a third-party purchaser of her shares.

136. See Stone, supra note 111, at 943-44.

137. Examples include target shareholders who must choose between receiving cash or stock consideration from an acquirer and shareholders who must choose whether or not to participate in their corporation's offer to redeem its stock. Id. at 944.

138. See Arthur W. Andrews \& Lawrence R. Wilson, Stock Dividend Taxation Under the Tax Reform Act of 1969: Expansion of an Ominous Past, 13 ARIZ. L. REV. 751, 751-52. 767-80 (1971) (criticizing $\S 305(b)(2)$ for introducing unnecessary complexity and uncertainty into Code).

139. Stone, supra note 111 , at 915 . 
ownership percentage of their investments without suffering immediate, ordinary income tax liability. ${ }^{140}$ Like-kind exchanges, ${ }^{1+1}$ transfers to controlled corporations, ${ }^{142}$ and corporate reorganizations ${ }^{1: 3}$ are among the most salient examples of tax-free investment transformations. ${ }^{1: 4}$

More illustrative examples include share repurchase plans and new issues of equity to the public. A share repurchase plan provides each shareholder with the option to tender her shares to the firm for cash. Those who do not tender their shares will increase their interest in the firm vis-à-vis those shareholders who do tender. Thus, the economic consequence of a share repurchase plan is very similar to that of a dividend option. Nontendering shareholders in a share repurchase plan, however, are not taxed. Consider also new public issues of equity. When a firm floats a new issue of shares to the public. every current shareholder has the option to buy new shares. Shareholders who elect not to buy new shares will suffer a decrease in their interest in the firm. Yet, they are not treated as if they bore a loss for tax purposes. These examples show that the economic reality for those who choose to receive stock dividends in a dividend option plan is not very different from the reality faced by other shareholders who engage in nontaxable business transactions.

Eliminating $\S 305(\mathrm{~b})$ from the Internal Revenue Code would not have a traumatic effect on the U.S. system of corporate taxation. The justifications for $\S 305$ (b) are far from strong. The reform may cause the fisc to lose some revenue, ${ }^{145}$ but Congress can easily employ a simple and small hike in the corporate income tax rate to restore the size of the fisc. Eliminating \$305(b) would allow a firm to replace its reinvestment plan with an option mechanism covering the firm's full accumulated earnings. Firms would no longer actually need to distribute dividends before shareholders exercised their options. Each shareholder would determine her own individual payout ratio, based on both the firm's internal profitability and her personal tax bracket. A shareholder would select a cash dividend only when the sum of a tirm's internal profitability, the value of a stock dividend's tax deferral, and the value of gain

140. Id. at 925 .

141. I.R.C. \$1031 (1994).

142. Id. § 351 .

143. The provisions of the Internal Revenue Code governing curporate reorganizations afe legion See. e.g., id. $\S \S 354,361,368$.

144. See Stone, supra note 111 , at 925-28.

145. According to one estimation. U.S. investors are annually paying $\$ 8$ to S18 billion in taxes that they could have avoided if firms had retained earnings. Crockell \& Fnend. supra note 50. at 603. Taxing an option based on its actual exercise would reduce significantly overall Treasury iax receipis from dividends. It is hard to predict how much tax revenue would be lost. Many firms mught adopt the option mechanism and commit their full earnings to potential distribution. How much of these carnings will be retained depends on both the firm's relative internal profitability and shareholders" individual ax brackets. A study of a closely related issue estimated that the Treasury would lose approximately SI billion dunng the first year of the tax-deferred status of reinvested dividends, would break even in the second year, and would gain about $\$ 1.5$ to $\$ 2.0$ billion in the third year. See Fredman \& Nichols. supra note 119. at 77 
re-characterization was less than the best alternative rate of return. ${ }^{146} \mathrm{~A}$ taxexempt shareholder, who cannot enjoy tax deferral or re-characterization of gain, would decide how to exercise her option based solely on the firm's relative internal profitability.

Under the current business practice of stable dividend policies, a firm's payout ratio reflects the average investor's desires and cannot accommodate the wishes of all shareholders. If a payout ratio is too high, a shareholder can either hold on to the stock and pay more taxes than she desires, or she can exchange her shares for those of a more thrifty company and pay the transaction costs involved in making purchases and sales in the stock market. The option mechanism would ensure that a firm possessed an optimal "tax clientele": Each year shareholders would select their own individual payout ratios. ${ }^{147}$ The proposed tax change, by itself, would enable firms that switched to an option mechanism to offer a higher return than firms that paid stable dividends, other things being equal. Because each shareholder could tailor her own individual payout, minimizing her taxes if she so desired, investors would demand a lower return from the firm's equity and the stock price would rise. From the tax perspective, therefore, it is reasonable to predict that most firms would switch to an option mechanism after the repeal of $\S 305(b) .^{148}$

Modifying $\S 305$ of the Code is the least drastic way of removing the tax distortion. Taxing the option based on its actual exercise, however, still favors retention of earnings over dividends because shareholders prefer to defer taxes and to pay taxes at capital gains rates rather than at ordinary income rates. Other things being equal, this structural tendency towards earnings retention will rise in proportion to the values of tax deferral and gain re-characterization to a given shareholder. For example, a tax-exempt shareholder would be indifferent between equally productive retained earnings and cash dividends; a high tax-bracket shareholder, on the other hand, would favor retention of earnings over cash dividends.

The tax preference for earnings retention should not greatly impede the shift of control over dividend policy to the capital markets. But the tax

146. A small shareholder, who might find it too expensive to make an informed decision, can cither follow the actions of more sophisticated investors or accept the payout ratio recommended by management. The mere existence of the option does not make her worse off.

147. In other words, every firm can have every investor as its sharcholder (i.c., "client"), regardless of the shareholder's tax bracket.

148. Whether the tax advantage is sufficient to induce all firms to shift control over their dividend policy to the capital markets is uncertain. The benefit conferred by taxing an option based on its actual exercise depends on each firm's (former) stable dividend payout. The lower the original payout, the smaller the tax benefit. Moreover, the shift of control would be costly for inefficient firms, mainly because an option mechanism would improve capital markets discipline. Therefore, inefficient managers would weigh the costs of exposure to improved market discipline against the tax benefit. Given that incfficient firms would have initially low dividend payouts, it is reasonable to assume that the tax benefit would not always outweigh the "lost" agency costs for the managers. 
preference for earnings retention will influence the level of inefficiency that a firm can reach before shareholders will opt for cash dividends. That is, while tax-exempt shareholders will opt for dividends as soon as the firm's internal profitability falls below that of alternative investments, a high tax-bracket shareholder will wait longer-until the value of alternative investments exceeds the firm's internal profitability by the value to her of capital gain characterization and deferral. ${ }^{149}$ Therefore, eliminating $\S 305(b)$ will not provide optimal allocative efficiency. Indirectly, however, the reform will increase the degree to which markets discipline managers. In those firms with tax-exempt, institutional investors that both hold large blocks of stocks and engage in close monitoring, the shareholders will detect even a slight deterioration in efficiency and might follow up on their discovery by converting a substantial amount of firm earnings into cash dividends. Consequently, in firms with large institutional investors, management will be subject to effective supervision despite the tax preference of other shareholders for earnings retention.

\section{Total Integration of Corporate Tax}

Another alternative for eliminating the tax distortion is a total integration of the corporate and personal income taxes. This alternative would equalize the tax consequences of ordinary stock dividends and optional stock dividends by abolishing the benefit of tax deferral presently accorded to stock appreciation. In a completely integrated tax system, shareholders would be taxed in a manner similar to partners in partnerships; that is, the corporate tax would be eliminated, and corporate income would be attributed directly to shareholders. ${ }^{150}$ Shareholders would lose the ability to defer taxes, and stock dividends would be taxed the same as cash dividends. Because shareholders must pay tax on the firm's full earnings in any case, firms would at least try to gain the benefit of distribution: reduced agency costs through a shift of control over dividend policy to the capital markets.

Given the option, each shareholder will decide for herself whether to allow retention of earnings. Under an integrated tax system, however, personal tax consequences will not influence the decision. Because an integrated tax system will attribute a pro rata portion of corporate earnings to each shareholder, regardless of whether earnings are retained or distributed, a shareholder's tax liability will not be affected by whether she chooses a cash or a stock dividend. The sole criterion for deciding whether to allow earnings retention

149. This phenomenon illustrates the resource misallocation argument against wex deferral. See. e.g.. Fellows, supra note 111 , at 727 (demonstrating how desire to avoid realization of gaun dnves investors to make inefficient decisions).

150. See, e.g., David F. Bradford, U.S. Dep't of the Treasury, BUUErints for Basic TaX REFORM 69 (2d ed. 1984); FoX, supra note 9. at 371. 
would be the firm's internal profitability relative to other investment alternatives. The result would be effective capital markets discipline and efficient firm performance. ${ }^{151}$

The debate among tax scholars over integration is intense. ${ }^{152}$ Partial integration, a commonly proposed compromise, would not fully remove the tax distortion. Partial integration would preserve the basic tax structure, but would allow corporations to deduct a portion of their dividend distributions, as interest payments, from their taxable income. ${ }^{153}$ In a different version, corporate-level taxes paid on dividends would be partially credited to the shareholder as a withholding tax. Although such a system would reduce the taxation of dividends relative to retained earnings, it would still favor the latter over cash dividends. ${ }^{154}$ In other words, partial integration would increase the firm's optimal dividend payout, but it would not enable a complete and unprejudiced shift of control over dividend policy to the capital markets.

\section{Taxation Without Realization}

A third alternative is negating the preference that the current tax system gives stock appreciation over cash dividends. ${ }^{155}$ The current tax system taxes capital gains at a lower rate than ordinary income and awards stock appreciation the benefit of tax deferral. The Code could provide for the taxation of investors' shareholdings on an accrual basis-that is, the Code could determine that capital gains on stock will be treated as if realized at some predetermined date in every taxable year. ${ }^{156}$ In such a tax system, true realization of gain would not be a necessary condition for taxation. Without the realization requirement, cash dividends would be taxed in the same manner as are retained earnings - the latter would produce stock appreciation and face

151. Total integration would eliminate the corporate-level tax and confer on shareholders a windfall. This tax benefit would not depend on the firm's dividend policy. Unlike the alternative of climinating $\S 305(b)$, in the wake of integration, a firm would achieve no tax benefits by switching to an option mechanism. Thus, for the same reasons that managers adopt defensive tactics and reincorporate in states with strong antitakeover legislation, it can be predicted that they will not voluntarily shift control over dividend policy to the capital markets.

152. See, e.g., Thomas D. Griffith, Integration of the Corporate and Personal Income Taxes and the aLI Proposals, 23 SANTA Clara L. Rev. 715 (1983) (advocating adoption of American Law Institute proposals for partial integration of corporate and personal taxes rather than dividend relief because latter produces windfall gains for current shareholders); U.S. DEP'T OF THE TREASURY, INTEGRATION OF THE INDIVIDUAL AND CORPORATE TAX SYSTEMS: TAXING BUSINESS INCOME ONCE (1992).

153. See, e.g., OFFCE OF THE SECRETARY, U.S. DEP'T OF THE TREASURY, 2 TAX REFORM For FAIRNESS, SIMPLICITY, AND ECONOMIC GROWTH: THE TREASURY DEPARTMENT REPORT TO THE PRESIDENT 136 (1984) (suggesting 50\% dividend deduction).

154. See Fox, supra note 9 , at 373.

155. For a comprehensive analysis of this alternative, see Fellows, supra note 111; Shakow, supra note 133.

156. A sale of stock would still be a realization event. 
taxation on a statutorily deemed realization date. ${ }^{157}$ The above analysis regarding total integration is, therefore, equally applicable here. ${ }^{198}$

A tax distortion prevents firms from voluntarily adopting an option mechanism. Paving the way for efficient firms to adopt an option mechanism requires some tax reform, at least the moderate tax reform of taxing an option based on its actual exercise. ${ }^{159}$ Removing the tax distortion will not be sufficient to reduce agency costs, however, because inefficient or opportunistic managers will still be able to refuse to adopt the option mechanism for their firm. Consequently, I turn in the next Part to consider public policies that address this concern.

\section{DiRect Regulation OF Dividend POLicy}

Because managers enjoy their discretion over dividend policy, removing the tax distortion will not suffice to induce inefficient managers to adopt the option mechanism. Direct regulation of dividend policy may be necessary to force inefficient managers to relinquish their discretion. Mandating the option mechanism is justified as a means to prevent the social waste produced by agency costs. ${ }^{160}$ Mandating the option mechanism will compel inefficient firms to shift discretion over dividend policy to shareholders and thereby subject the firm to the control of the capital markets. Consequently, a

157. This tax reform measure would annul tax deferral benefits and would ental a substantial inerease in the effective tax rate on capital gains. A common objection to taxing capital garns is that such a tax reduces investment hquidity. Note. however, that the "lock-in" problem assoctated with the traditional capital gains tax will not exist if the realization requirement is abolished. Without the realizalion requirement, tax deferral becomes impossible and the incentuse to remain in an inefficient investment vanishes as well. I do not attempt to decide here which of the above altemauves should preval Rather. 1 argue that the tax distinction between stock appreciation and stock dividends received upon an option to acquire either cash or stock dividends is unjusufied. Once a shareholder opts for slock dividends, she deserves the same treatment as a shareholder who makes profits through stoch apprecialion Either both should enjoy tax defertal (as in the altemative discussed in Part II. B I) or both should suffer immediate taxation (as in this altemative).

158. See supra par Il.B.2.

159. In the United States. corporate law is state lau Wthout a change in the federal tax laws, no state will adopt a legal rule mandating dividend options. If a state were to mandate dividend options. "t would be imposing higher taxes on the firms incorporated in the state. and the Federal Treasury would collect the added tax revenues. Given the empetition among states for corporate charters. It is imational for any individual state to adopt such a mandatory rule. The mavenck state will bear the cost of firms reincorporating outside the state and the cost of fewer future incorporations The benefits of the nule will flow into the Federal Treasury and into other states, which will benefit from inereased incorporations and reincorporations in their jurisdiction. Thus, no individual state will adopt such a mandatory rule unless all other states do the same. Even if all states adopt the rule, however, another distortion might remain. If only firms with publicly traded stock are required to issue dividend options. they will be at a disadvaniage relative to private firms and other investments and asscts.

160. The option only shifts control over divdend policy to shareholders. without endangering management's overall control of the firm. The chief lobbies in favor of antitakeover statutes are corporate managers and local corporate lawyers who fear losing their jobs and losing their clients respectuvely. See Roberta Romano. The Future of Hostile Takeovers: Legislation and Public Opinion. 57 U CIN. L. REv. 457, 461-63 (1988). Because the option mechantsm does not create these nsks, and because of its posituve infiuence on shareholders, option legislation is desirable and may have a realistic chance of becoming law 
mandatory option mechanism will reduce social waste by deterring suboptimal investments ex ante.

\section{A. The Feasibility of Dividend Options}

Is it possible to draft a practical law that would require all firms to adopt an option mechanism? A positive answer to this question depends on the satisfactory resolution of two issues: (1) preservation of working capital; and (2) enforcement of constraints that creditors place on dividend distribution. Professor Fox, who was the first scholar to consider a universal dividend payout rule ${ }^{161}$ as a means of improving industrial performance, rejected such a rule because of its inability to ensure that a firm could preserve necessary working capital and would abide by dividend constraints imposed by creditors. ${ }^{162}$ This Section shows how these administrative obstacles to a mandatory option can be circumvented.

\section{Defining Earnings and Working Capital}

The core practical problems of a mandatory dividend option are identifying the level of earnings that must be distributed and determining the level of working capital that must be preserved. ${ }^{163}$ Corporate law regimes have

161. A universal payout rule is "a rule that would assure that large, publicly traded corporations would generally pay out to shareholders some minimum portion, perhaps all, of their earnings and depreciation flows." Fox, supra note 9, at 383.

162. See id. at 400 . Fox concluded, using information economics analysis, that a universal payout rule would reduce inferior investments by improving the allocation of funding to projects with high predicted retums, increasing sensitivity to innovative real investment proposals, and reducing business concentration. Id. at 384. Fox rejected the universal payout rule as impractical, in part because of the difficulty faced by entities other than management in determining the appropriate level of working capital (a problem that tho next Subsection addresses). Id. at 400-01. Instead, Fox advocated a rule that would

require each large, publicly traded corporation to seek outside financing each year in the form

of long-term debt or equity in an amount ... . equal to a given percentage of all additions to

property, plant, and equipment . . . . Management under the proposed formulation would have Id. at 401 .

the same freedom to determine its level of dividends as it does now.

Fox's proposal can be explained by his focus on the need to facilitate the flow of information through the capital markets. My focus on the need to restrict agency costs, however, suggests that such a solution is unacceptable. If, as Fox proposed, a firm must raise outside financing cach year but need not distributc dividends, free cash flow will increase and the problem of agency costs will worsen. Fox suggested that management would not be motivated to retain more earnings than necessary; if management really had no incentive to retain an excessive amount of earnings, however, why would Fox want to force firms to seek outside financing in the first place? Under his proposal, efficient firms would be able to raise outside financing, but they would incur unnecessary transaction costs. Inefficient firms, in contrast, would find outside financing so expensive that it transfers wealth from the old shareholders to the new holders of debt or equity. In either case, Fox's proposal does not solve the agency-cost problem, and it either creates waste or damages old shareholders.

Note that outside financing plays an important role in reducing agency costs in my analysis as well. See supra text accompanying notes 28-38. Outside financing should come into play indirectly, however, only after dividends have been distributed.

163. The assumption is that some corporations need to preserve part of their earnings as working capital, in order to maintain their current investments and operations. See RosS ET AL., supra note 2, at 
encountered these problems in the past: In the nineteenth and early twenticth century, several states adopted rules mandating dividend distribution. ${ }^{160}$ The problem of identifying distributable earnings first arose at a time when terms such as "accumulated earnings" were not defined in the statutes and did not have an obvious meaning. Given the complexity of the concept of earnings and the absence of a concrete definition of the term, it was easy for managers to manipulate their calculation of earnings; consequently, it was hard for states to enforce the dividend payout laws. Today, however, it should be possible to define earnings clearly and to calculate them with an algorithm. ${ }^{1 \text { s }}$ Fox concluded that "[m]odern accounting conventions combined with more careful statutory drafting would make this kind of problem much less severe today." 166

The related problem, determining working capital, is more critical. The cases interpreting the old mandatory dividend payout laws reveal that any rule directly compelling a large percentage of profits to be paid out, if enforced without exceptions, would impose extreme hardship on some corporations. To mitigate this potential hardship, the laws allowed firms to retain a fraction of their earnings as working capital, to be used for financing their day-to-day operations. The dividend laws never succeeded in determining the amount of working capital that would be both suitable to all firms and sufficient to compel the appropriate level of distribution. They usually required that a firm retain a fixed amount of earnings as working capital that, depending on the firm, was either too high or too low. ${ }^{167}$ Fox envisioned that any universal payout rule would suffer from the same problem, and hence concluded that the rule was inflexible and impractical. ${ }^{168}$

I believe that Fox's view is inaccurate. The problem of defining working capital is truly complex for any rule mandating a large, nondiscretionary dividend distribution. Allowing management to determine the amount of working capital necessary to finance ordinary business operations would be

192-93.

164. "New Jersey, North Carolina, and New Mexico each enacted statutes in the late mueteenth and early twentieth century requiring all, or a set percentage of all. profits to be pasd out as dividends." Fox. supra note 9, at 399.

165. The Intemal Revenue Code's treatment of corporate distnbutuons of propeny to shaseholders hinges on the concept of "earnings and profits": "[T] he term 'dividend" means any distnbution of property made by a corporation to its shareholders ... out of its eamings and profits .... I.R.C. $\$ 316$ (a) (1994). The concept of "earnings and profits" plays a prominent role in seicral areas of the tax law besides Identification of dividends. See, e.g., id. $\$ \S 304(\mathrm{~b})(2), 305(\mathrm{c}), 306(\mathrm{c})(3) .355(\mathrm{a})(1)(\mathrm{B}), 356(\mathrm{a})(2)$. $56(\mathrm{~g})(4)(\mathrm{B})(\mathrm{i}), 1362$ (d)(3). 1368(c). 1375(a)(1). While the tax authorities have had some interpretuve difficulties with the concept, it maintains a central importance in the field of corporate taxatson Set BITTKER \& EUSTICE. supra note $115 . \S 8.03$.

166. Fox, supra note 9. at 399. Although managers tend to overstate the firm's earnings in thetr reports to the stock market (in order to increase stock pnces and their compensalion), the option mechanism would encourage managers to understate their earnings (in order to limit dividends). The conflicting tendencies will lead managers to report eamings more accuratcly.

167. Id. at $399-400$.

168. Id. at $400-01$. 
tantamount to granting management discretion over dividend policy anew. The least problematic solution, although far from perfect, is to allow shareholders to make the decision regarding working capital. Shareholder dividend options do not impose full distribution of earnings without discretion. Each shareholder has discretion over her own dividend payout. The aggregate decision of individual shareholders determines the actual dividend payout ratio of the firm.

Dividend options might be a dangerously poor method of determining working capital, however, if shareholders would, in fact, almost always opt for full distribution. Such behavior would make the option tantamount to a mechanical mandatory rule compelling full distribution and no preservation of working capital. Fortunately, there are good reasons to suppose that shareholders will not act in this way. Assuming equal tax rates on retained earnings and cash dividends, ${ }^{169}$ a shareholder's decision on how much earnings to retain would depend on the firm's internal profitability. This decision would be influenced only by the expected return on reinvested earnings compared to the expected return on other investment opportunities. The expected return on the existing equity investment is already impounded in the stock price. A shareholder who believes that the expected return on the

169. To analyze the payout ratio that is likely to result under the option mechanism, it is necessary to assume a certain tax system. Three tax regimes are possible: where the effective tax rate on retained earnings is equal to, lower than, or higher than the tax rate on cash dividends. It is clear that full distribution of corporate earnings is unlikely in a tax regime that imposes a lower tax rate on retained earnings. Full distribution becomes probable only in a tax regime that imposes a much lower tax rate on dividends. For my present purposes, in order to focus on business elements, I will climinate tax considerations by assuming equal effective tax rates.

Taxing cash dividends at a lower rate than retained earnings could effect a shift in control over dividend policy to the capital markets without requiring amendments to state corporate law. For instance. Germany taxes retained earnings at $56 \%$ and taxes cash dividends at only $36 \%$ (including shareholders' tax); Japan taxes retained earnings at between $31 \%$ and $43.4 \%$ while it taxes cash dividends at betwcen $25 \%$ and $33.3 \%$ (including sharehoiders' tax). ANG, supra note 37, at 17. Under such a tax regime, cven if the capital gains tax rate were zero, all shareholders would prefer dividends to retained carnings. Given shareholder preferences, firms have a strong incentive to distribute cash dividends. See, e.g., Michel \& Shaked, supra note 116, at 380 (comparing several Japanese and American industries and concluding that Japanese industries' payout ratios were higher in all cases where test results were significant).

These foreign tax regimes are designed in part to promote financing through the capital markets. Sec Morris Mendelson, Payout Policy and Resource Allocation, 116 U. PA. L. REV 377.380 n.18 (1968). In other words, although management formally maintains its discretion over dividend policy, in practice there is a high tax cost to exercising this discretion in favor of retention. Shareholders, therefore, constrain managerial discretion. An efficient management will distribute as much profit as possible so that shareholders can enjoy the lower tax on cash dividends. Consequently, shareholders, recognizing the quality of their firm, will reinvest the proceeds in the firm.

On the other hand, an inefficient management, aware of the risk that cash dividends arc unlikely to be reinvested, will attempt to retain earnings. Any unnecessarily retained earnings will be heavily taxed, leading to a substantial discount in the stock price. The larger the discrepancy between dividend tax rates and retained earnings tax rates, the more expensive it will be for management to retain earnings, and the greater will be the stock price discount. If the sum of this discount and the discount resulting from the suboptimal investment is significant, the firm will be a potential target for a takeover. Given that tax inefficiency is much easier to observe than suboptimal investment, search costs for potential acquirers will be low. The very fact of significant earnings retention in the face of inferior tax treatment would also signal managerial entrenchment. Moreover, the transparency of tax-inefficient behavior would make it much casier for insurgents to win a proxy fight. Subject to all these monitoring mechanisms, management should bc adequately deterred from behaving in a self-serving fashion. 
existing equity investment is low will sell the stock, because holding it and opting for a cash dividend will not generate higher returns. If enough shareholders join her and sell, the stock price will decline, and the stock will offer a higher return. In other words, those shareholders who hold the stock and exercise the dividend option (opting for either cash or stock dividends) are those who believe that the return on the existing equity investment is satisfactory. The question they face when exercising the option is, therefore, whether an additional investment will also generate a satisfactory return.

A decision of the shareholders will determine the amount of retained earnings needed for growth and the amount of earnings needed to preserve the existing investment (working capital). A divergence of opinion among shareholders regarding the firm's future growth prospects is very likely. More optimistic shareholders will allow the firm to retain more earnings. Each shareholder will receive a stock dividend to the extent of her desire for retention. Consequently, a shareholder will increase her stake in the firm to the extent that other shareholders desire the firm to retain less earnings than she does. ${ }^{170}$ The aggregate amount of retained earnings will reflect the sum of all individual retention decisions. An aggregate of zero should not be considered problematic: It merely reflects the shareholders' view that there are outside investments that are better than the one proposed by management. Indeed, the option mechanism is designed to enable shareholders to prevent suboptimal managerial investment. Nevertheless, divergence of opinion among shareholders should lead to some earnings retention in every firm.

On the other hand, the option mechanism does need some modification to assure that the firm retains sufficient earnings to preserve the rate of return on the existing investment. As long as a dividend distribution of one dollar produces no more than a one-dollar decline in the firm's value, the option mechanism assures optimal reinvestment (as a measure of the aggregate true preferences of shareholders). If, however, a one-dollar distribution produces a decline in firm value of greater than one dollar, the option mechanism might not ensure optimal investment. In some rare cases, shareholders might face a coordination problem that leads to suboptimal retention.

An example may be useful. Suppose a firm earns $\$ 20$ per share, of which it distributes $\$ 15$ to shareholders and reinvests $\$ 5$ each year. The $\$ 5$ annual reinvestment is necessary to maintain the $\$ 15$ annual dividend. The stock is expected to earn the same return in perpetuity, and its capitalization rate is $10 \%$. Thus, the stock sells for $\$ 150$ per share. ${ }^{171}$ If the firm does not reinvest the $\$ 5$, however, it will earn only $\$ 15$ in the subsequent year, $\$ 3$ of which must be reinvested to maintain a $\$ 12$ annual dividend. The stock would then

170. In this respect, the option plan is the same as a new issue of "nghis" or "warrants" Shareholders who exercise the right to buy more stock increase their share in the firm relative to those who do not

171. Price $=$ dividend $/$ capitalization rate $=\$ 15 / 0.1=\$ 150$. 
sell for $\$ 120$ per share. Failure to reinvest the $\$ 5$ in any year will cost shareholders a $\$ 25$ loss per share ( $\$ 30$ stock depreciation minus $\$ 5$ in extra dividend). A responsible management, therefore, would reinvest $\$ 5$ and distribute $\$ 15$ every year. The question is whether individual shareholders would also make this decision.

Consider the case in which all shareholders have full information and no divergence of opinion exists among them. Each shareholder fears that the others will, mistakenly, try to take the full earnings out ( $\$ 20$ instead of $\$ 15$ ), as that seems to offer the highest personal return for the current year. Put differently, each shareholder recognizes the need to reinvest the $\$ 5$, but also fears that the others will not join her in reinvesting and will thereby cause her damage to the extent of her reinvestment. In this case, shareholders face a coordination problem. ${ }^{172}$

For simplicity, assume that there are only two shareholders, each of whom owns one share of stock. If both reinvest $\$ 5$, they preserve the value of the firm ( $\$ 150 \times 2=\$ 300)$ and lose nothing. If neither reinvests, the value of the firm drops to $\$ 240$, the stock price drops to $\$ 120$ per share, and each of them receives $\$ 5$ extra in dividend but loses $\$ 30$ in stock value. Finally, if one shareholder reinvests the necessary $\$ 5$ (receiving a proportionate stock dividend), ${ }^{173}$ but the other reinvests nothing, two alternatives are possible: (1) the partial reinvestment mitigates the price drop (the value of the firm is somewhere between $\$ 245$ and $\$ 295$ ); or (2) the partial reinvestment does not mitigate the price drop (the value of the firm equals $\$ 245$ ). ${ }^{174}$

In the former case, where reinvestment by one shareholder mitigates the drop in share price, unilateral reinvestment will probably mitigate the loss of

172. Game theory distinguishes between coordination problems and prisoner's dilemmas. A coordination problem exists whenever two players (decision makers) do not have a conflict of intercst, but the preferred action of each is conditioned on the action of the other. If these two players could communicate with each other, they would coordinate their behavior and agree to take the action preferred by both. A prisoner's dilemma, on the other hand, exists whenever two players have conflicting interests, each has a preference independent of the other's choice, and the final outcome is one that neither of them prefers. Even if the two players could communicate with each other and coordinate their behavior, as long as they could not enter into an enforceable agreement, they would still act according to their individual preference and end up in a situation neither prefers. See R. DUNCAN LUCE \& HowARD RAIFFA, GAMES AND DECISIONS chs. 5-6 (1957).

173. At the beginning of the year, each stock sells for $\$ 150$. Before the option is exerciscd, the value will rise to $\$ 165$ to reflect the accumulated dividend. The additional earnings of $\$ 5$ do not lead to an increase in stock price, as the market expects the $\$ 5$ to be reinvested. Thus, the value of the firm is $\$ 330$, and the theoretical firm value after distribution of $\$ 15$ to both shareholders equals $\$ 300$. Calculating the value of each share then is somewhat complicated. $X$ (share price) $=\$ 300$ (firm value) $/(1+5 / X+1+$ $5 / X$ ). The value of the stock dividend received by each shareholder is $5 / X$ ( $\$ 5$ reinvested $/$ the new share price). Solving the above equation for $X$ yields $\$ 145$ per share. A reinvesting shareholder therefore receives a stock dividend of $5 / 145$ of a share.

174. Without mitigation, the value of the firm equals $\$ 120$ plus $\$ 120$ plus the $\$ 5$ reinvested. With mitigation, the value of the firm equals $\$ 120$ plus $\$ 120$ plus the $\$ 5$ reinvested plus some mitigation factor. The value of the firm cannot exceed $\$ 295$ because complete mitigation would produce a firm with a valuc of $\$ 300$ (firm value with the optimal $\$ 10$ reinvestment) minus $\$ 5$ (earnings removed by the shareholder who did not reinvest). 
the reinvesting shareholder. ${ }^{175}$ Although the unilaterally reinvesting shareholder will lose more than the abstaining shareholder, the reinvesting shareholder will probably lose less by reinvesting than by abstaining, despite the other shareholder's abstention. Yet the reinvestment of one shareholder also mitigates the loss of the abstaining shareholder. While the abstaining shareholder can share part of the return on the reinvestment, she would be able to eliminate her loss completely by also reinvesting. That is, she is better off also reinvesting than attempting to free ride on the other shareholder's reinvestment. Therefore, the rational shareholder should almost always reinvest, regardless of the other shareholder's action, ${ }^{176}$ and optimal retention should occur.

In the second case, where the reinvestment of one shareholder does not mitigate the price drop, the value of the firm falls to $\$ 245 . .^{m}$ Notwithstanding her reinvestment, the reinvesting shareholder would suffer a loss of $\$ 25.42 .{ }^{178} \mathrm{Had}$ she not reinvested, she would only have lost $\$ 25 .{ }^{179}$ Therefore, it is not profitable for one shareholder to reinvest unless the other shareholder reinvests as well. The abstaining shareholder recoups $\$ 5$ from avoiding reinvestment and shares part of the $\$ 5$ reinvestment of the other shareholder. The loss of the abstaining shareholder is $\$ 24.58 .{ }^{180}$ The reinvesting shareholder loses more than the abstaining shareholder, but both lose. That is, each shareholder prefers reinvestment only if the other

175. The reinvesting shareholder would have lost $\$ 25$ if she had not reinvested (\$30 drop in share price minus $\$ 5$ in extra dividend). As long as her $\$ 5$ reinvestment keeps the firm's value above $\$ 245.83$. the reinvesting shareholder was wise to reinvest. If the firm has a value of \$245.83. the abstauning shareholder will hold one share, the reinvesting shareholder will hold I + 5/145 stures, see supra note 173 . and therefore each share of stock will be worth $\$ 120.83$. The reinvestung shareholder will have stock worth $\$ 125(\$ 120.83 \times(1+5 / 145$ shares $))$. Her loss, then, will be $\$ 25(\$ 150-\$ 125=\$ 25)$. If firm value exceeds $\$ 245.83$, then her loss will be less than \$25.

176. For example, if one shareholder reinvests. the value of the firm drops to $\$ 270$ (including the $\$ 5$ reinvestment) instead of falling to \$245. The value of each share of stock would be \$132.7) (\$270/(1+ $1+5 / 145$ shares)). The reinvesting shareholder would have slock worth $\$ 137.29(\$ 132.7) \times(1+5 / 145$ shares)) and the abstaining shareholder would have $\$ 137.71$ (\$132.71 plus avolded reinvestment of \$S). The corresponding losses are $\$ 12.71$ (\$150 - \$137.29) and \$12.29 (\$150 - \$137.71). The payoff matnx for each shareholder, given her election, is a classic prisoner's dilemma, but with an optimal outcome:

\begin{tabular}{||l|l|l|l||}
\hline \multicolumn{2}{|c|}{} & \multicolumn{2}{c|}{ INVESTOR 2 } \\
\cline { 2 - 4 } \multicolumn{2}{c|}{} & abstain & reinvest \\
\hline \multirow{3}{*}{ INVESTOR 1 } & abstain & $-\$ 25,-\$ 25$ & $-\$ 12.29 .-\$ 12.71$ \\
\cline { 2 - 4 } & reinvest & $-\$ 12.71,-\$ 12.29$ & $\$ 0 . \$ 0$ \\
\hline
\end{tabular}

177. See supra note 174 .

178. The firm's value is $\$ 245$. The total number of shares outstanding is $1+1+5 / 145$. The share price is therefore $\$ 120.42(\$ 245 /(1+1+\$ / 145))$; the value of the reinvesung shareholder's shares is $\$ 124.58(\$ 120.42 \times(1+5 / 145))$.

179. That is, $\$ 30$ in stock depreciation munus $\$ 5$ in exira dividend.

180. The price per share is $\$ 120.42$. See supra note 178 . The value of the abstanning shareholder's single share is also $\$ 120.42$, and the abstaining shareholder's loss is therefore \$2.4.58 (\$150 - \$120.42 - \$S extra cash dividend). 
shareholder reinvests as well, but if there is a high probability that the other will abstain, a shareholder will minimize her losses by also abstaining. ${ }^{181}$ Although shareholders face a coordination problem, because it is clear that collectively it is best for all shareholders to reinvest, rational and informed shareholders are very likely to reinvest, even without coordination. ${ }^{182}$

Nevertheless, where partial reinvestment does not mitigate the price drop, a joint reinvestment might not occur even though it is the preferable alternative for the shareholder community. If one shareholder fears that the others are irrational, insufficiently informed, or unable to calculate the correct strategy, then she might be better off avoiding the reinvestment. Under such conditions, abstention would minimize her potential loss. Similarly, each shareholder might "rationally" rationalize "irrationality" on the part of the other shareholders. Consequently, all shareholders might opt for full distribution, fail to preserve working capital, and suffer a loss. ${ }^{183}$ In such a case, a statutorily predetermined working capital requirement would be needed to preserve investment, and the dividend option would be rendered impractical.

Assuming such rational irrationality exists in the real world, a simple solution can assure joint reinvestment. To alleviate a shareholder's fear that her fellows will retain an insufficient amount of earnings, a drop in firm value will follow, and she will have made a foolish investment, the option mechanism could allow for conditioned reinvestment. ${ }^{184}$ Corporate law could permit each shareholder to reinvest on the condition that a certain minimum aggregate amount of retention results. Each shareholder would estimate for herself the minimum amount of earnings retention required to prevent a decline in the firm's value. If the firm does not achieve the shareholder's estimated

181. The payoff matrix is as follows:

\begin{tabular}{|c|c|c|c|}
\hline & & \multicolumn{2}{|c|}{ INVESTOR 2} \\
\hline & & abstain & reinvest \\
\hline \multirow{2}{*}{ INVESTOR 1} & abstain & $-\$ 25,-\$ 25$ & $-\$ 24.58,-\$ 25.42$ \\
\hline & reinvest & $-\$ 25.42,-\$ 24.58$ & $\$ 0, \$ 0$ \\
\hline
\end{tabular}

182. The game has two equilibrium pairs: Either both shareholders abstain or both reinvest. Yet neither shareholder has a dominant strategy. The decision of one shareholder depends on the decision of the other shareholder: Each would like to abstain when the other abstains and to reinvest when the other reinvests. Nonetheless, the equilibrium in which both abstain is jointly inadmissible, since both shareholders prefer the equilibrium in which both reinvest. In other words, the latter equilibrium jointly dominates the former equilibrium. The equilibrium in which both shareholders reinvest is therefore the solution to this game in the strict sense. See LUCE \& RAIFA, supra note 172, at 106-09.

183. In other words, the equilibrium in which both shareholders abstain might "psychologically dominate" the rational equilibrium. See id. at 109-10.

184. This solution is a variation on Professor Bebchuk's solution to the prisoner's dilemma in the context of a tender offer. See Lucian A. Bebchuk, Toward Undistorted Choice and Equal Treatment in Corporate Takeovers, 98 HARV. L. REv. 1695, 1747-50 (1985) (proposing regulation of hostile tender offers that would enable tendering target shareholders to condition their participation on success of takeover). 
minimum, the firm must cancel her reinvestment decision and distribute cash dividends to her instead. Given an ability to condition reinvestment on a sufficient aggregate retention, each shareholder will reveal her true retention preference and avoid investing in a firm with insufficient working capital. ${ }^{134}$ Optimal retention should result. ${ }^{186}$

The risk of suboptimal retention of earnings will only exist in rare cases: (1) where a firm needs working capital and does not offer growth opportunities; (2) where partial reinvestment by some shareholders will not mitigate a drop in stock price; and (3) where shareholders are unable to coordinate. In all other cases where retention is needed to preserve the value of the firm, there is no reason to assume that shareholders will act irrationally and compel destructive dividends. Furthermore, even in the rare case where a risk of destructive dividends exists, there is no need to set a predetermined level of working capital. Rather, structuring the option mechanism to allow conditioned reinvestment should ensure joint reinvestment.

In sum, three factors prevent distribution of destructive dividends and obviate the need to preserve working capital by legal rule. ${ }^{157}$ First, a divergence of opinion among shareholders will generally lead to an aggregate reinvestment reflecting average opinion. The more growth opportunities that the firm offers, the greater the prospect that the minimum amount of earnings will be retained. Second, the existence of large institutional investors and the ability of all shareholders to condition their reinvestment will facilitate coordination. Third, many shareholders will reinvest automatically, as they do now. Under current dividend reinvestment plans, many shareholders automatically reinvest after taxes on dividends have been paid. Some shareholders will also reinvest because they find the transaction costs of

185. A shareholder's fear that excessive retention of earnings would cause a drop in the price mercly reflects a difference of opinion with other shareholders as 10 the firm's future prospects A shareholder who thinks the firm should only reinvest $50 \%$ of eamings but who fears that the other shareholders will reinves! $100 \%$ of eamings could simply sell her shares to a more optumisuc investor.

186. The ability to condition reinvestment will relieve rational shareholders fear thal other shareholders will be irrational. A shareholder is able to take her preferred move with the assurance thal if others do not follow, she can change her election. A condiuonally reinvesung shureholder will not sulfer from the coordination problem.

The analysis thus far has involved imationality among rattonal shareholders. Truly imational shareholders, however. might abstain despite the availability of conditioned reinvesiment. which could lead to a chain reaction in which all other shareholders abstain by foree of falled conditional renvestments. Yet. there is no reason to assume that irrationality would always lead to abstention. While some imational investors might abstain, others might reinvest more than necessary and thereby counter the effect of the irrational abstainers. Moreover, irrationality would nol survive in the long run. given thal shareholders, to some degree, are repeat players. Finally, given the frequent divergence of opinion regarding a firm's need for working capital, many sharcholders' condition for reinvestment will not be inel. and the aggregate resulting reinvestment is likely to reflect average opinion.

187. To the extent that one insists on certainty and demands a working capital requirement. the requirement clearly should be minimal. French company law requires that a corporation allocale $5 \%$ of its annual profits to working capital; shareholder vote determines the fate of the residuum. See supra note 108 
switching investments too high. ${ }^{188}$ Other shareholders will reinvest because the tax penalty for disinvestment is too high. ${ }^{189}$ The shareholders who automatically reinvest will ensure that some modicum of earnings is always retained.

\section{Creditors' Constraints on Dividends}

Dividend options face a potentially more troubling problem than preserving working capital: determining the relationship between shareholder designations of earnings for distribution and creditor restrictions upon distribution. Shareholders and bondholders have sharply conflicting interests in the arena of dividend policy. A dividend payment to shareholders both compromises the priority that indentures generally provide to bondholders over the firm's cash flow, and increases the bondholders' risk of loss from a decrease in the value of the firm's assets. Bondholders prefer dividend payouts to be as small as possible; they attempt to achieve this objective through bond covenants. ${ }^{190}$ Restrictions on dividends are an important element in bond contracts because state statutory law and common law frequently provide creditors with insufficient protection. ${ }^{19}$ The ability to tailor dividend restrictions carefully offers a creditor excellent protection from shareholder opportunism and provides the firm with better terms for its debt. ${ }^{192}$

Once the option mechanism gives shareholders the ability to determine dividend distribution levels, shareholders may not voluntarily honor the firm's commitment to creditors not to distribute dividends above a stipulated level. If the law permits shareholders full discretion over the dividend decision, they

188. If a small shareholder recognizes that a firm has become less profitable, she will seck an alternative investment, a task that entails searching, information-gathering, and information-processing costs. For some shareholders, these costs would be higher than the additional return that could be gained in an alternative investment, and thus they would reinvest in their firm. It is important to note that although a small shareholder can observe the decision of a large shareholder as to whether to reinvest in the firm, she cannot easily observe the alternative investment that the large shareholder chose. That is, a small shareholder can observe that a large shareholder opted for dividends, thereby signaling a vicw of an insufficient internal profitability, but she cannot easily discover the alternative investment and take the same action. Nevertheless, even if it is always optimal for a small shareholder to reinvest (unless there is a material drop in the firm's prospects), she still benefits from the monitoring activities of a large sharcholder. See supra notes 95-99 and accompanying text. Management acknowledges the possibility that large shareholders can withdraw a large amount of earnings if faced by inefficient performance. This possibility deters management from making suboptimal investments, and all shareholders benefit.

189. If capital gains continue to receive preferential treatment from the tax code, few shareholders will opt for full distribution. Indeed, if the tax system favored dividends, as it does in Germany and Japan, sec ANG, supra note 37 , at 17 , there would be a risk that too many shareholders would opt for full distribution. A tax system that favors dividends, however, renders the option mechanism superfluous. If dividends enjoyed a sufficient tax preference over retained earnings, managers, who would still have full discretion over dividend policy, would distribute large dividends of their own volition. The large dividends would provide the capital markets with discretion over the reinvestment decision. See supra note 169.

190. See, e.g., Avner Kalay, Stockholder-Bondholder Conflict and Dividend Constraints, $10 \mathrm{~J}$. FiN. ECON. 211 (1982).

191. See ClARK, supra note 54 , at 610.

192. Smith \& Warner, supra note 75 , at 134 . 
might opt for a large distribution and increase the risk of the firm's debt, thus transferring wealth from bondholders to shareholders. Shareholders cannot bond themselves against this action because the identity of shareholders changes frequently.

To address this problem, the law should continue to deem binding a managerial commitment to creditors to limit dividend distribution. The law should permit this commitment to preempt shareholder rights to full designation of earnings under the option mechanism. Such a legal principle could, however, open the door to collusion between management and creditors to restrict dividends more than is necessary to protect the bondholders. ${ }^{193}$ Such collusion would frustrate the operation of the option mechanism and breach management's fiduciary duty of loyalty. In order to create a greater deterrent effect, courts should assign liability to creditors as well as to management. ${ }^{194}$

Collusion between managers and creditors can be prevented without relying exclusively on court scrutiny. One possible solution is to require a majority of independent directors to approve each bond contract that restricts distributions. Another possible solution is to require shareholder approval of restrictive bond contracts. ${ }^{195}$ Dividend restrictions are a common feature of debt financing, but they are imposed mainly by long-term debtholders. ${ }^{1 \%}$ Long-term debt contracts are infrequent in the business life of most firms. Consequently, requiring shareholder approval of long-term debt contracts would not significantly impede management's control over a firm's operation. Director or shareholder review of the bond contract might include asking for a competitive bid from another creditor or for an outside opinion on the necessity and reasonableness of the dividend restriction. If these contracts are to be subject to shareholder approval, management should present an alternative contract whenever possible, in order to enable shareholders to evaluate the restriction's value. Approval by independent directors or shareholders should be sufficient to ensure that a dividend restriction is reasonable and the result of an arm's-length transaction.

To summarize, dividend options will not fail to preserve a firm's working capital. In most cases, shareholders would use their discretion rationally; a firm can avoid the occasional problem of destructive dividends by allowing for conditioned reinvestment. The risk of collusion between management and

193. See John C. Coffee, Jr., Unstable Coaltions. Corporate Gavemance as a Mulu.Player Gume. 78 GEO. L.J. 1495 (1990) (discussing consequences of deal making between managers and bondholders).

194. In the ultimate analysis, it is a question of choosing belween a rulc that would require courts to scrutinize the dividend policy itself and a rule that would require courts to examine the propnety of creditors' constraints on dividends. As I demonstrate tater. courts are betier able to perform the latter task. See infra part IIl.B. Put differently. I advocate shifting from a "duty of care" to a "duty of loyalty" test.

195. For an identical proposal in a similar context, see Edward B. Rock. Controlling the Dark Side of Relational Investing. 15 CARDOZO L. REv. 987. 1023-24 (1994).

196. See Smith \& Warner, supra note 75 , at 134-35. 
creditors can also be minimized by requiring shareholder approval of bond indentures. Firms can design the other elements of the option (e.g., the number of dates for exercising the option, the procedures for exercising the option, the statute of limitations) so as to assure efficient operation.

\section{B. The Role of the Courts}

A state corporate law mandating dividend options should limit itself to structural intervention. That is, the law should transfer discretion over dividend policy from management to shareholders; it should not attempt to determine firms' dividend policies. A properly circumscribed option mechanism will not affect any entrepreneur's substantive business judgment. Instead, it will shift the right to make the substantive business decisions regarding dividend policy from management to shareholders. ${ }^{197}$ The importance of restricting legal intervention to structural aspects becomes clearer upon even a cursory examination of the institutional competence of courts.

Under current law, the business judgment rule protects management's control over dividend policy. Courts have established the rule that directors possess sole discretion over whether or not to declare dividends. Unless management abuses its discretion, the courts will not interfere. ${ }^{198}$ This rulc removes any effective limits on managers' distribution decisions. One might argue that courts have simply accepted the dividend irrelevance theorem: Shareholders should have no right to compel dividends because dividend policy will not affect the firm's value. The actual reason for judicial nonintervention, however, is more practical. Determining a firm's dividend policy, or even the appropriate size of a single distribution, is a complicated matter. At the least, it requires considerable knowledge of a firm's internal affairs and its overall economic position. Courts are reluctant to substitute their judgment for that of management, a body of people with more knowledge about the firm and more expertise in making business decisions. Because courts are ill suited to scrutinize a decision as complex as establishing a firm's dividend policy, they compel distributions in only limited circumstances: fraud, bad faith, and gross mismanagement. Therefore, a shareholder's suit to compel dividend distribution, based on the claim that management is investing in bad projects, has precious little chance of succeeding.

Yet many scholars, including myself, have argued that there is a need for intervention. ${ }^{199}$ The main argument for intervention is the conflict of interest

197. Restricting dividend options to a mere shift of discretion ensures their suitability for all firms. As the above analysis of working capital shows, see supra part III.A.l, there are good reasons to think that shareholders would select an appropriate payout ratio. It is unlikely that they would opt for zero dividends when their firm had a host of new profit opportunities.

198. See supra notes 7-8 and accompanying text.

199. See supra note 10. 
between shareholders and management over dividend policy. Most proposals for change fail to acknowledge the limited ability of courts to review the propriety of business decisions. This failure to recognize the institutional incompetence of courts dooms these proposals.

One commentator has suggested that courts should not protect management's dividend decisions with the business judgment rule because the dividend decision involves an inherent conflict of interest between management and shareholders. ${ }^{200}$ This line of thinking implies that a properly reformed jurisprudence and more aggressive courts could solve the agency-cost problems of corporate governance. This implication is clearly problematic since courts employ the business judgment rule precisely because of their institutional inability to second-guess business decisions. Suppose that the courts partially abandoned the business judgment rule and placed the burden of proof on management to defend its dividend policy. How would courts determine whether a given dividend policy is "correct"? Given judicial inability to scrutinize business decisions effectively, management might become excessively prodigal with the firm's retained earnings in order to avoid a lawsuit. ${ }^{201}$ In any case, courts are probably worse than self-interested managers at crafting a firm's dividend payout policy.

Other scholars have argued that courts could determine the appropriateness of a given firm's dividend policy by comparing it to the dividend policies of similar firms in the same industry. Judges could employ statistical tools to calculate an average payout ratio for similar firms, which would serve as a benchmark for reasonableness. This proposal suffers from three salient defects. First, the proposal cannot eliminate judicial second-guessing of complex business decisions. Even the scholars advocating this judicial tack admit: "Of course, management would have the opportunity to present whatever circumstances it may deem proper to justify its purposes for having a payout ratio differing significantly from that of the industry norm (mean)." proposal only channels the judicial inquiry by slightly restricting the kind of business considerations that management can offer to justify its dividend decisions. Courts are no more competent to analyze these focused justifications than they are to analyze unfocused justifications. Second, even assuming the economic appropriateness of using an industry mean payout ratio as a guide (a troubling assumption in itself), courts would find themselves constantly examining the adequacy of the statistical procedures employed to calculate industry means. Third, there is every reason to expect that many industries systematically distribute an inappropriately meager amount of dividends. An

200. See Israel, supra note 8 , at 98.

201. Courts still face the problem of evaluating managerial justufications for a given durdend policy. Regardless of who has the burden of proof, evaluating these proferred justufications remains a complex tasx.

202. C. Wayne Shepherd \& David F. Scolt, Jr., Corporaie Disudend Policy: Some Legal and Financtal Aspects, 13 AM. BUS. L.J. 199. 223 (1975). 
intra-industry dividend payout ratio comparison will not detect these sorts of industry-wide inefficiencies.

Some state legislatures have taken a different approach: compelling firms to distribute a predetermined ratio of dividends to earnings each year. ${ }^{203}$ In theory, this bright-line rule should have obviated the need for judicial scrutiny of a firm's dividend policy. Unfortunately, this approach to dividends has had little success. First, state laws left many important terms undefined; courts had to define complex concepts such as "accrued earnings." Second, these innovative state legislatures recognized the importance of qualifying their dividend laws so as to prevent hardship to unusual firms. The duty to decide whether a firm fell within the scope of a given exception naturally devolved upon the courts. Courts did not prove equal to the task, and their inability to assess the ramifications of business complexities eventually led to the failure of these attempts to control dividend policy by law.

Finally, one commentator has suggested that states adopt a corporate law rule that compels management to provide relevant information to shareholders whenever management changes a firm's dividend policy. ${ }^{204}$ Even assuming the wisdom of such a rule in the abstract, how are courts to determine the adequacy of the information provided to shareholders in practice? Scrutinizing informational adequacy under this rule would afflict courts with the same difficulties that they would have in directly examining a firm's dividend policy. This rule would simply shift the focus of scrutiny from the action itself-adopting a dividend policy-to the information underlying the action.

Any proposal advocating judicial intervention in managerial discretion over divided policy must acknowledge that courts are poorly equipped to secondguess complex business decisions. A salient advantage of dividend options is that they would require minimal judicial supervision. Dividend options would not require courts to determine the appropriateness of any dividend policy; rather, the capital markets would make this substantive business decision. For several reasons, the capital markets are best suited to make and supervise this business decision. First, the capital markets have extensive knowledge about the firm and the requisite expertise for examining the appropriateness of the firm's dividend policy. Second, the capital markets have substantial experience in reviewing firms' investment potential-they perform this role every day when pricing stocks or supplying new funds to firms. Third, the capital markets have the proper incentives in establishing a firm's dividend policy-investors will fully bear the costs of any decision to override management's judgment.

Shareholder dividend options would relieve the courts of the difficult task of scrutinizing dividend policy. With most aspects of the option mechanism

203. See supra note 164.

204. See Brudney, supra note 10 , at 114 . 
defined by law, courts would become purely mechanical enforcement ministries. Courts would only have to supervise firms' adherence to the terms of the option: e.g., establishment of option exercise dates, timely and accurate distribution of cash to shareholders opting for cash dividends, timely and accurate distribution of stock to shareholders opting for stock dividends, and compliance with designated accounting methods. Dividend options limit the courts' role to one of fairly technical supervision. Restricting courts to tasks that they can feasibly perform is a chief merit of the option mechanism.

\section{CONCLUSION}

Efficiency dictates that corporate law shift control over dividend policy from management to the capital markets. This shift will give the capital markets control over a substantial portion of firm financing and will thereby increase the amount of direct capital markets discipline over firms' performance. Giving the capital markets discretion over the reinvestment decision will significantly reduce the agency costs of corporate governance. Shifting control over dividend policy to the capital markets will also assist firms in achieving more efficiently the goals they now strive to reach through a stable dividend policy. The best means of effecting the shift is through a corporate law rule that requires firms to provide their shareholders with the periodic right to opt for either cash or stock dividends. ${ }^{205}$

Today even efficient firms will find it too expensive to switch to an option mechanism because our system of corporate taxation treats shareholder options to receive cash or stock dividends as taxable cash dividends regardless of whether a shareholder actually elects to receive cash. Even without the tax distortion, however, most inefficient firms would refuse to subject themselves to the scrutiny of the capital markets by shifting control over dividend policy to shareholders. Both of these impediments-the tax distortion and managerial reluctance to relinquish control-warrant regulatory intervention.

At the least, Congress should remove the tax distortion that discourages efficient firms from voluntarily shifting control. The least objectionable method of removing the distortion would be to tax dividend options based on their actual exercise. More d-astic measures would involve either total integration

205. It is possible that enabling legislation, in the form of an opt-out provision. might be sufficient to economize on agency costs. To prevent current and future shareholders from oblasning disidend options. management would need to persuade a majority or supermajonty of current shareholders to vote to rejeet dividend options. The adequacy of such an enabling provision would depend upon the individual ownership structure of a firm. A-management that holds substant:al stock in the firm would find it easter to opt out, but as management's holdings increase. the nsk of agency costs decreases and the need for the option mechanism decreases pro tanto. Enabling legistation containung an opt-in provision, on the other hand, would allow management to take advantage of collective action problems and shareholder apathy. because management controls the proxy mechanism and meeting agendas. I will have a much easier ume avoiding an opt-in option mechanism. 
of the corporate tax or elimination of the realization requirement from the law of federal income taxation. To goad balking, inefficient firms, state legislatures ought to mandate the option mechanism, and thereby enhance the level of capital markets scrutiny of earnings reinvestment decisions.

Reform should be gradual, starting with the removal of the tax distortion. After observing how firms respond to this change in a free-market environment, state legislatures can decide whether there is a need to facilitate adoption of the option mechanism by enacting enabling legislation, e.g., an opt-out provision. The last stage of reform would depend on the success of the enabling legislation to reduce agency costs. If enabling legislation is ineffectual, state corporate law ought to mandate the option. Gradual implementation and observation of market responses would enable decision makers to better guide each stage of the reform.

Facilitating a shift of control over dividend policy from management to the capital markets is both desirable and feasible. Legal reform that facilitates such a shift will increase significantly the ability of the capital markets to discipline firms directly, thus improving firms' performance and minimizing the need for the cruder and more costly control measure of the hostile takeover. 